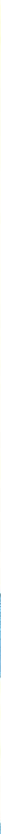

\title{
SPACE HEATING SYSTEMS IN THE NORTHWEST - ENERGY USAGE AND COST ANALYSIS
}

\section{ENERGY RESEARCH AND DEVELOPMENT ADMINISTRATION}




\section{DISCLAIMER}

This report was prepared as an account of work sponsored by an agency of the United States Government. Neither the United States Government nor any agency Thereof, nor any of their employees, makes any warranty, express or implied, or assumes any legal liability or responsibility for the accuracy, completeness, or usefulness of any information, apparatus, product, or process disclosed, or represents that its use would not infringe privately owned rights. Reference herein to any specific commercial product, process, or service by trade name, trademark, manufacturer, or otherwise does not necessarily constitute or imply its endorsement, recommendation, or favoring by the United States Government or any agency thereof. The views and opinions of authors expressed herein do not necessarily state or reflect those of the United States Government or any agency thereof. 


\section{DISCLAIMER}

Portions of this document may be illegible in electronic image products. Images are produced from the best available original document. 


\title{
Printed in the United States of America Available from \\ National Technical Information Service \\ U. S. Department of Commerce \\ 5285 Port Royal Road \\ Springfield, Virginia 22161
}

Price: Printed Copy $\$ 5.50$; Microfiche $\$ 2.25$

\begin{abstract}
NOT I CE
This report was prepared as an account of work sponsored by the United States Govermment. Neither the United States nor the Energy Research and Development Administration, nor any of their employees, nor any of their contractors, subcontractors, or their employees, makes any warranty, express or implied, or assumes any legal liability or responsibility for the accuracy, completeness or usefulness of any information, apparatus, product or process disclosed, or represents that its use would not infringe privately owned rights.
\end{abstract}


ANCR-1276

DISTRIBUTION UNDER CATEGORY:

UC-95d

Energy Conservation-Buildings and Industry TID-4500, R63

SPACE HEATING SYSTEMS IN THE NORTHWEST - ENERGY USAGE AND COST ANALYSIS

J. G. Keller

J. F. Kunze

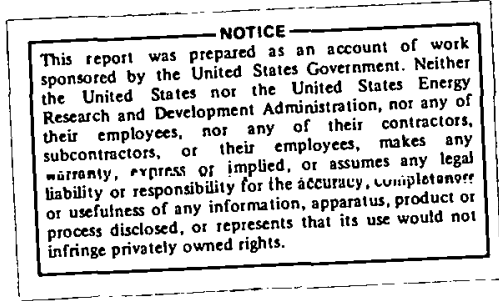

AEROJET NUCLEAR COMPANY

Date Published - January 1976

PREPARED FOR THE U. S. ENERGY RESEARCH AND DEVELOPMENT ADMINISTRATION IDAHO OPERAT IONS OFFICE

UNDER CONTRACT NO: $E(10-1)-1375$ 
THIS PAGE

\section{WAS INTENTIONALLY LEFT BLANK}


This study addresses the question of energy usage and cost of providing space heat in the Northwest. Though space heating needs represents only $18 \%$ of the U.S.'s total energy consumption, it nevertheless appears to offer the greatest potential. for conservation and near term applications of alternate energy sources.

Efficiency and economic feasibility factors are considered in providing for space heating demands. These criteria are presented to establish energy. usage,cost effectiveness and beneficial conservation practices for space heating of residential, commercial, and industrial buildings.

Four Northwestern cities have been chosen whose wide range of $\mathrm{cl}$ inlate conditions are used to formulate the seasonal fuel and capital cost and hence the annual heating cost covering a broad spectrum of heating applications, both the traditional methods, the newer alternate forms of energy, and various methods to achieve more efficient utilization of all types.

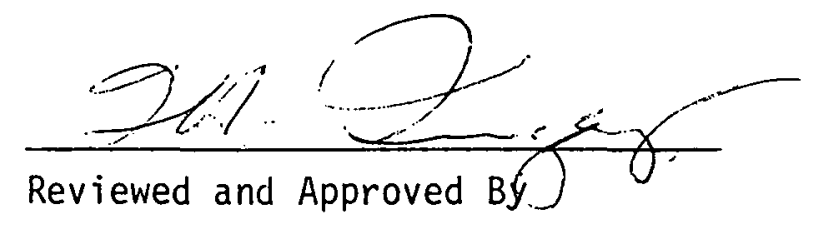


ABSTRACT. ............................ $i$...

1.0 INTRODUCTION. . . . . . . . . . . . . . . . . . . 1

2.0 SPACE HeATING REQUiREMENTS. . . . . . . . . . . . . . 14

3.0 HEATING SYSTEMS ........................... 17

3.1 Total Air Systems . . . . . . . . . . . . 17

3.2 Steam and Water Systems . . . . . . . . . . 17

3.3 Heat Pump Use . . . . . . . . . . . . . 18

3.4 Electric Systems. . . . . . . . . . . . . 20

3.5 Geothermal Space Heating Systems. . . . . . . . 20

3.6 Solar Heating Systems . . . . . . . . . . . . 20

3.7 Waste Heat Systems. . . . . . . . . . . . 23

3.8 Hybrid Solar - Heat Pump System . . . . . . . . . . 23

3.9 Wind Energy ... . . . . . . . . . 23

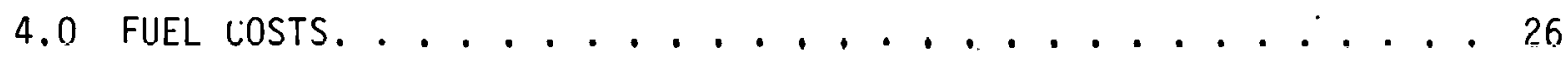

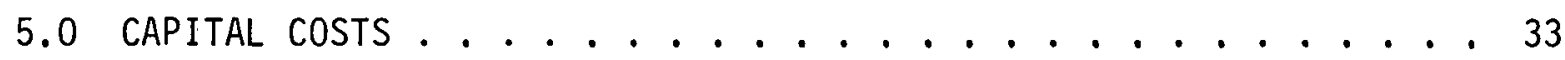

6.0 TOTAL COSTS OF HEATING SYSTEMS. . . . . . . . . . 38

7.0 CONCLUSIONS . . . . . . . . . . . . . . . . 43 REFERENCES. . . . . . . . . . . . . 46

\section{FIGURES}

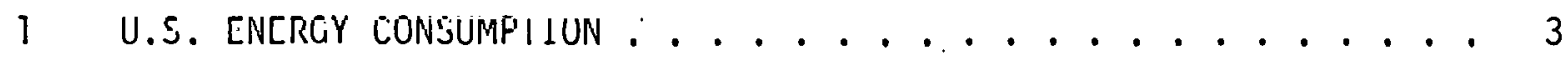

2 PACIFIC NORTHWEST ENERGY CONSUMPTION. . . . . . . . . 4

3 SOURCES OF ENERGY - U.S. \& PNW. .............. 5

4 DISTRIBUTION \& POPULATION ................. 6

5 FACTORS CAUSING INCREASE IN ENERGY SALES TO DOMESTIC CONSUMERS. . 7

6 HEAT LOAD TYPICAL MOUERN HOME . . . . . . . . . . . . 19 
TABLE OF CONTENT (Cont inued)

FIGURES

Page

7 SOLAR HEAT SYSTEM. ................ 22

8 HEAT PUMP SYSTEM . . . . . . . . . . . . . . . 24

TABLES

I 1975 PER CAPITA ANNUAL ENERGY CONSUMPTION. . . . . . . . 8

II AVERAGE ANNUAL HOME ENERGY CONSUMPTION UPPER SNAKE RIVER

VALLEY ....................... 8

III SUMMARY OF PERTINENT CLIMATOLOGICAL AND METEOROLOGICP.L DATA. 9

IV SUMMARY OF PERTINENT CLIMATOLOGICAL AND METEOROLOGICAL DATA. 10

$\checkmark$ SPACE HEATING FUEL COST PROVIDEd by a SINGLE SOURCE. . . . . 11

VI. SPACE HEATING SYSTEMS BY TRANSFER MEDIUM........... 12

VII - PRESENT AND PREDICTEd RESIDENTIAL FUEL COSTS . . . . . . 27

VIII RESOURCE QUANTITIES NEEDED PER HR' $\mathrm{F}$ AS A FUNCTION OF HEATING SYSTEM TYPE AND RESOURCE USED. . . . . . . . . . 28

ix ANNUAL FUEL COST - PENDELTON, OREGON . . . . . . . . 29

$X \quad$ ANNUAL FUEL COST - SAN FRANCISCO, CALIFORNIA . . . . . 30

XI ANNUAL FUEL COST - BOISE, IDAHO. . . . . . . . . . 31

XII ANNUAL FUEL COST - IDAHO FALLS, IDAHO . . . . . . . 32

XIII FIRST COSTS - PENDELTON, OREGON. .......... 34

XIV FIRST COSTS - SAN FRANCISCO, CALIFORNIA . ........ . 35

XV FIRST COSTS - BOISE, IDAHO . . . . . . . . . 36

XVI FIRST COSTS - IDAHO FALLS, IDAHO . . . . . . . . 37

XVII ANNUAL HEATING COSTS - PENDELTON, OREGON . . . . . . 39 
TABLE OF CONTENT (Continued)

\section{TABLES}

Page

XVIII ANNUAL HEATING COST - SAN FRANCISCO, CALIFORNIA. . . . . 40

XIX ANNUAl hEATING COST - BOISE, IDAHO ......... 41

XX ANNUAL HEATING COST - IDAHO FALLS, IDAHO . . . . . . . 42 
Space heating requirements for 1975 are approximately at $14 \times 10^{15}$ Btu/year, or $18 \%$ of the total U.S. energy demand for 1975 ( 1 . With such large requirements for energy, some discretion should be used in choosing space heating systems to provide the maximum utilization of available resources. Efficiency and economic feasibility factors should be conisdered in this choice.

The Northwestern U.S. region, comprising Utah, Wyoming, Montana, Idaho, Oregon, and Washington, represents extremes of heating requirements--from the relatively moderate climate of the Pacific coast to the extreme winter conditions experienced in the high mountain plateau regions. Aside from these extremes, the Northwestern U.S. has specific uniquenesses making its energy situation different from the other regions of the contiguous 48 states. Much of the area (a11 except the extreme eastern part) has very meager indigenous resources of the conventional fuels of coal, oil, and gas. Yet the area has an abundance of developed hydroelectric facilities. Consequently, the area is a highly electric economy, as shown in Figures 1,2, and 3, compared to the U.S. in general. Presently, the Northwest is $60 \%$ more "electrified" than the rest of the U.S. This trend will continue though the gap will narrow. The rest of the United States will be building more and more electric generating plants (the majority nuclear), thus decreasing its fractional dependence on gas and oil.

The future projections of the Northwest area are perhaps of more significance than the current sttuation. The population of these six states is 8.5 million ( $4 \%$ of the U.S. total), with half of it concentrated along the narrow coastal band west of the Cascades, in Washington and Oregon. Yet the total area of these six states is $19 \%$ of the total area of the contiguous 48 states.

Population projections indicate a much faster growth rate in the area than will be typical of the nation. In addition, the area already is young for its population pyramid. If we build a population pyramid that shows the present Northwest population by 5-year age groups, the bottom of the pyramid witl have those between 0 and 19 years of age, who will be in the prime working year by 1990. (Figure 4) Near the middle of the pyramid are those between 45 and 64 who will be retired at that time. The difference between those leaving and those entering the working years is about 1,100,000. We must provide jobs for more than 800,000 young people--the children who are already here. This is one-third greater than the present Northwest labor force and is going to take a lot of additional energy to provide those jobs.

Table I lists comparative energy statistics for today (1975). It may appear surprising that the Northwest presently has a lower per capita total energy consumption thian the rest of the U.S. This is attributed largely to the extensive use of hydroelectric power, a much more efficient means of using energy. Unfortunately, future realistic expansion of the hydroelectric capacity cannot possibiy meet the expansion needs of the area, and nuclear and coal thermal electric plants will represent the major additions, as will be true for the rest of the U.S.

This document concentrates on space heating because it represents what is perhaps the energy usage that has the most potential for savings via 
conservation or alternate approaches. There is even more potential for improvement in the Northwest because of two factors:

1. The very large space heating needs of the mounta in plateau areas, where much of the growth in population is likely to occur. Table II shows the typical residential energy usage in such an area, while Tables III and IV show climatic data for two of the typical cities.

2. The very common use of electric resistant heat in new buildings and in retrofits since approximately 1950. The inexpensive hydroelectric power plus the utility minimum demand at night when space heating needs were greatest cause utilities to provide rate reduction incentives for all electric homes. Unfortunately, if the electricity is produced by fossil-fueled thermal plants (as much of it will in the Norhtwest in the future), electric resistance heating is a wasteful form of supplying space heat. And with nuclear plants, where fuel costs and future fuel supplies are not critical, the cost of electric resistance heating is costly, compared to the other alternatives. This heavy emphasis on recent electrical growth on space heating applications is shown in Figure 5. It should be noted that the chart applies only to the "West group" of Bonneville Power Association utilities, the area where the climate is mildest.

Space heating needs can be satisfied by various energy resources. For each of these, conversion to useful heat energy is accompanied by an efficiency 10ss. This study presents an energy and cost analys is of various space heating concepts whose ultimate criteria are: 1) the conversion or direct use of energy to maintain acceptable human comfort levels and 2) the maximum utilization of each source for cost effectiveness and beneficial conservation purposes. If all of the U.S. space heating needs could be provided by a single resource, the cost and quantity required for that source would be as shown on Table $V$.

This cost analysis for space heating systems was based on the heat transfer medium (i.e., hot water, steam, hot air, electricity) which would be available by a district heating plant, individual complex heating plant, or an individual residence heating unit. Heating unit terminal devices are analyzed for their annual costs in relation to the energy source used and the size of the heating system (district heat, complex heating systems, or individual residence).

Table VI lists the space heating systems discussed in this report. Four types of buildings were selected for comparing these heating systems and for calculation of heating load and fuel requirements for each case. 
BTU

QUADRILLION (10 $\left.10^{15}\right)$
U.S. ENERGY CONSUMPTION $1920-1990$

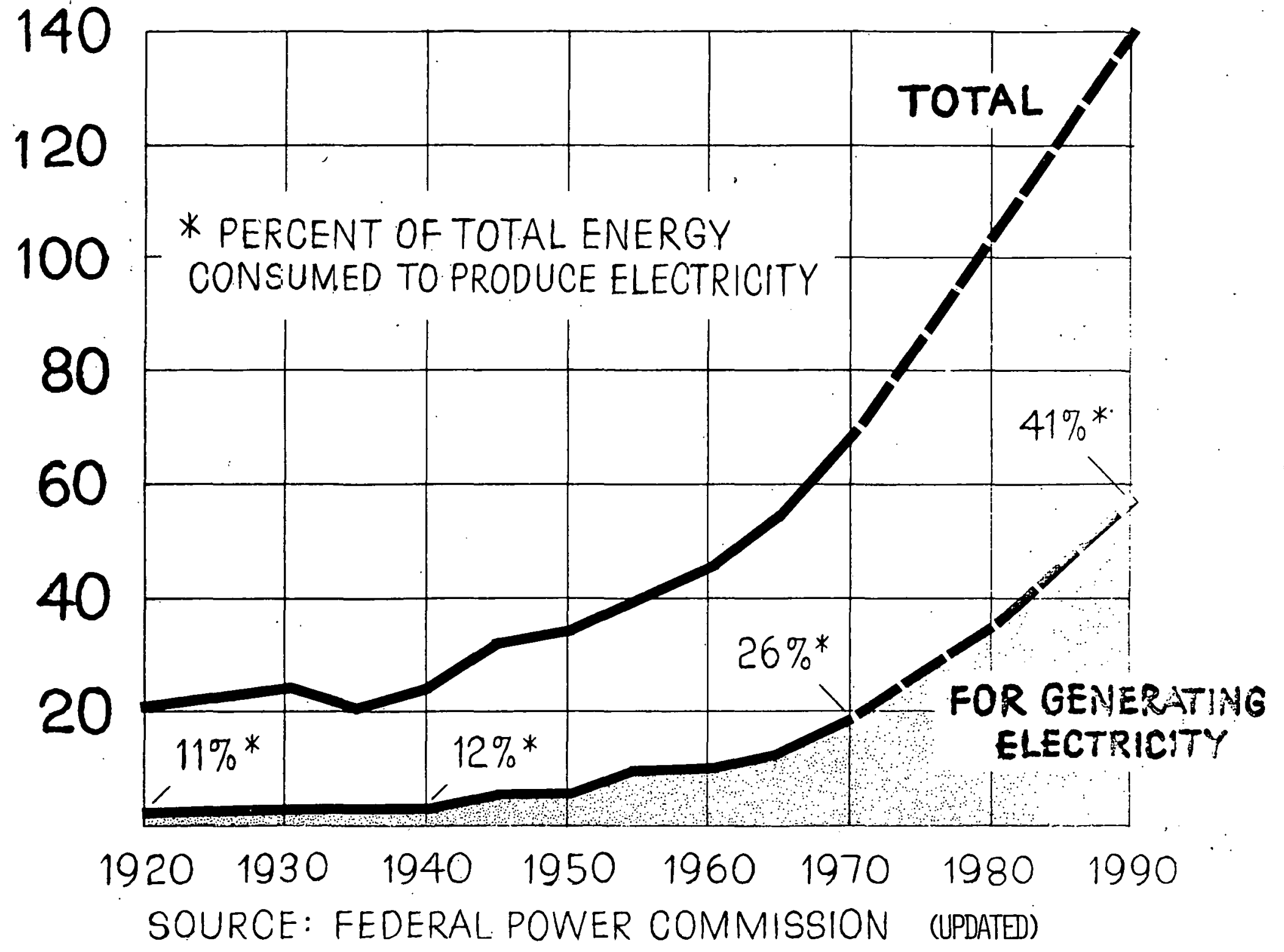

Fig. 1 


\section{PACIFIC NORTHWEST ENERGY CONSUMPTION BY ENERGY SOURCE 1950-1990}

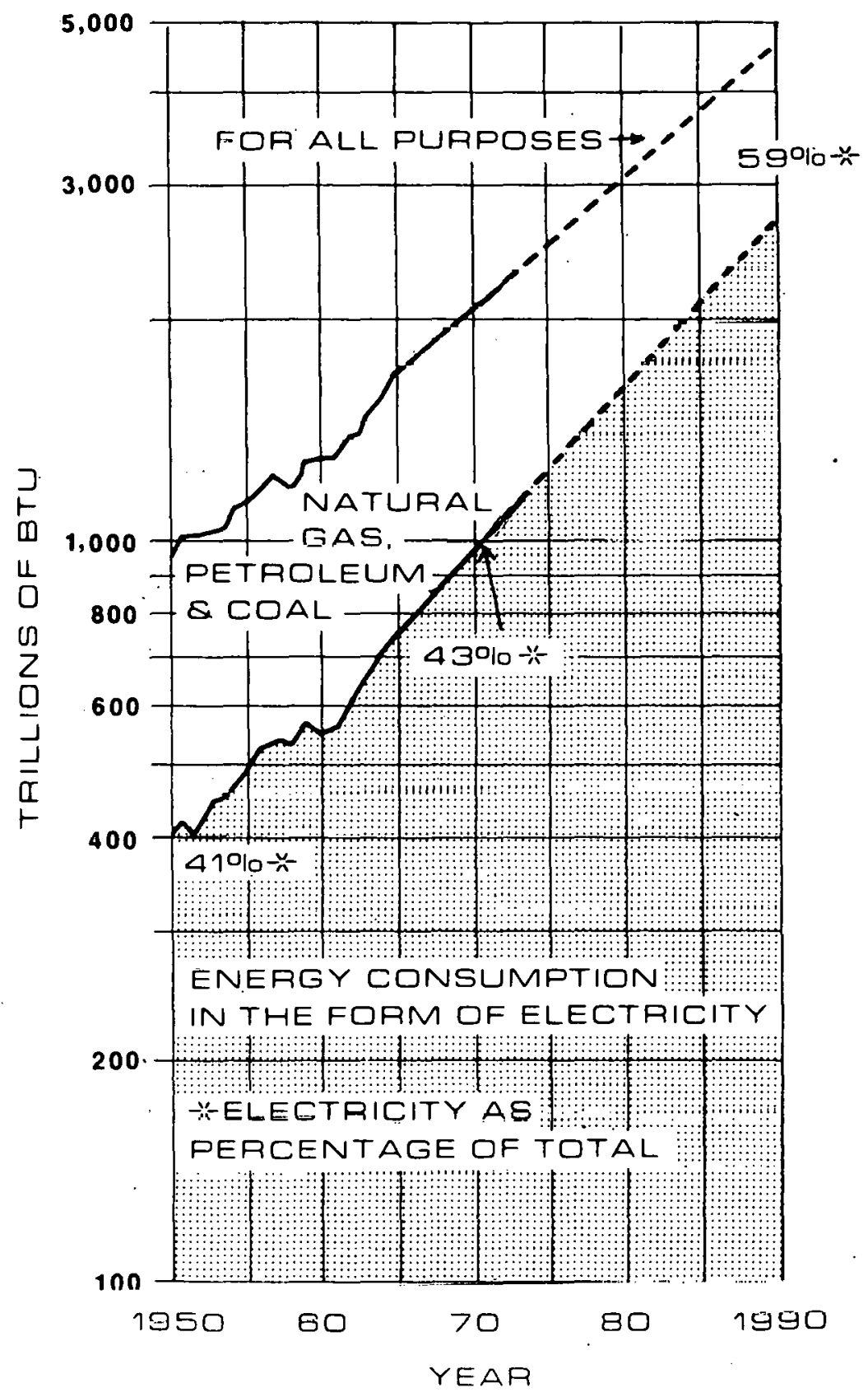

Fig. 2 (Sourcé: Bonneville Power Administration)

(U.S. Department of Interior Energy Fact Sheets) 


\section{SOURCES OF ENERGY-U.S. \& PNW}

บ.S.

PNW

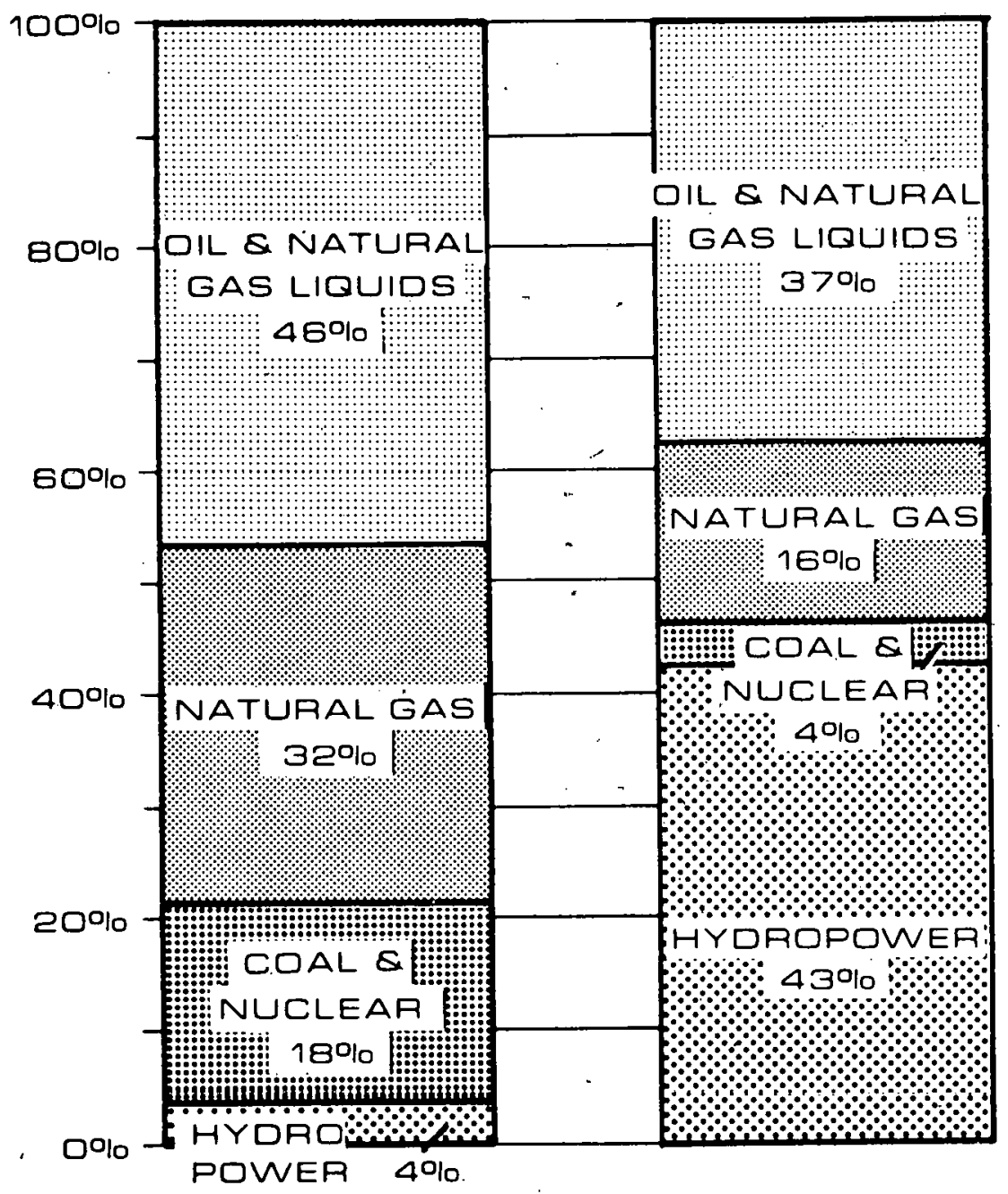

Fig. 3 (Source: Bonneville Power Administration) 


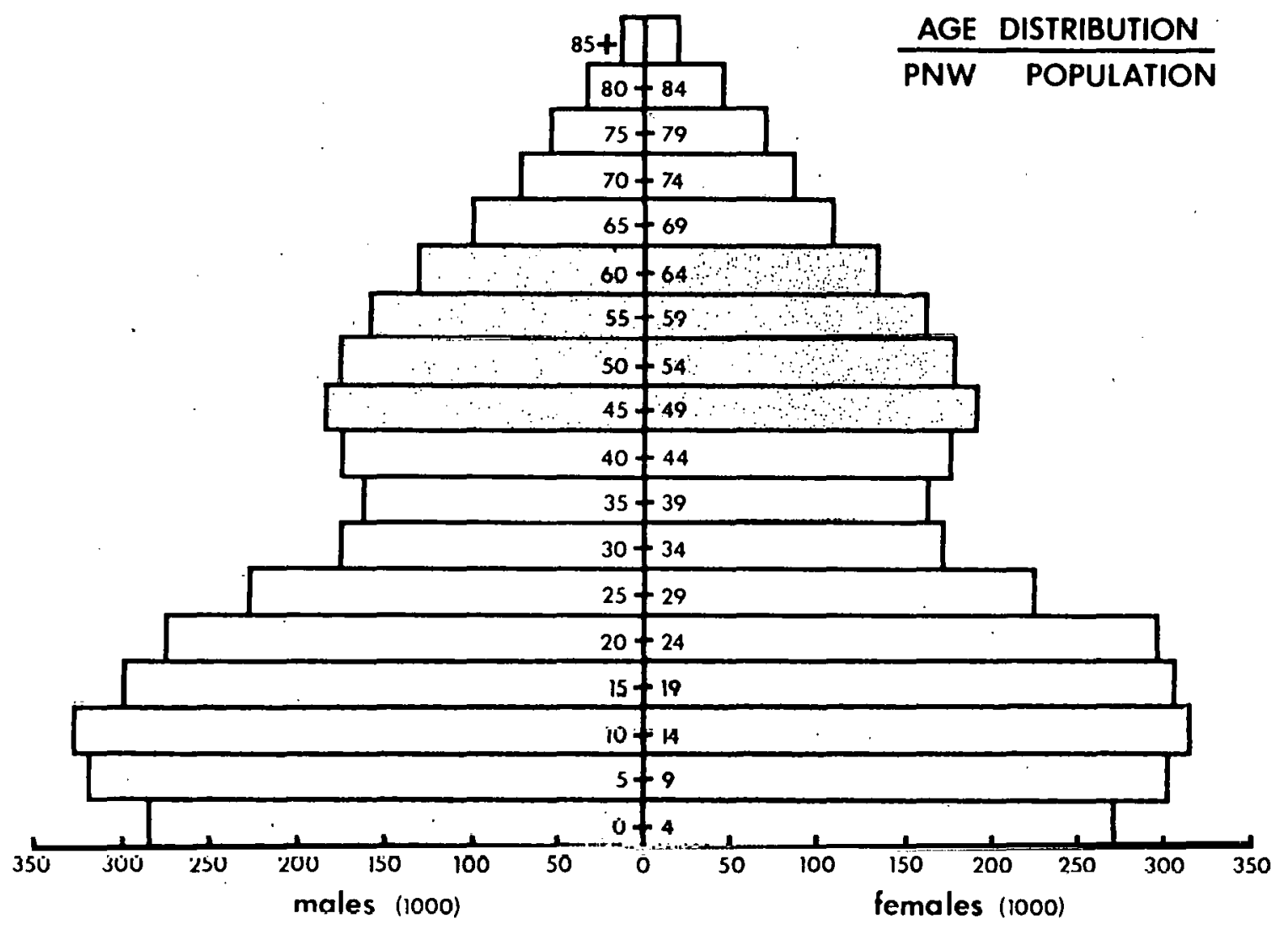

Fig. 4 (Source: Bonneville Power Administration) 
FACTORS CAUSINE: INCREASE IN ENERGY SALES TO DOMESTIC CONSUMERS IN WEST GROUP OF PNW
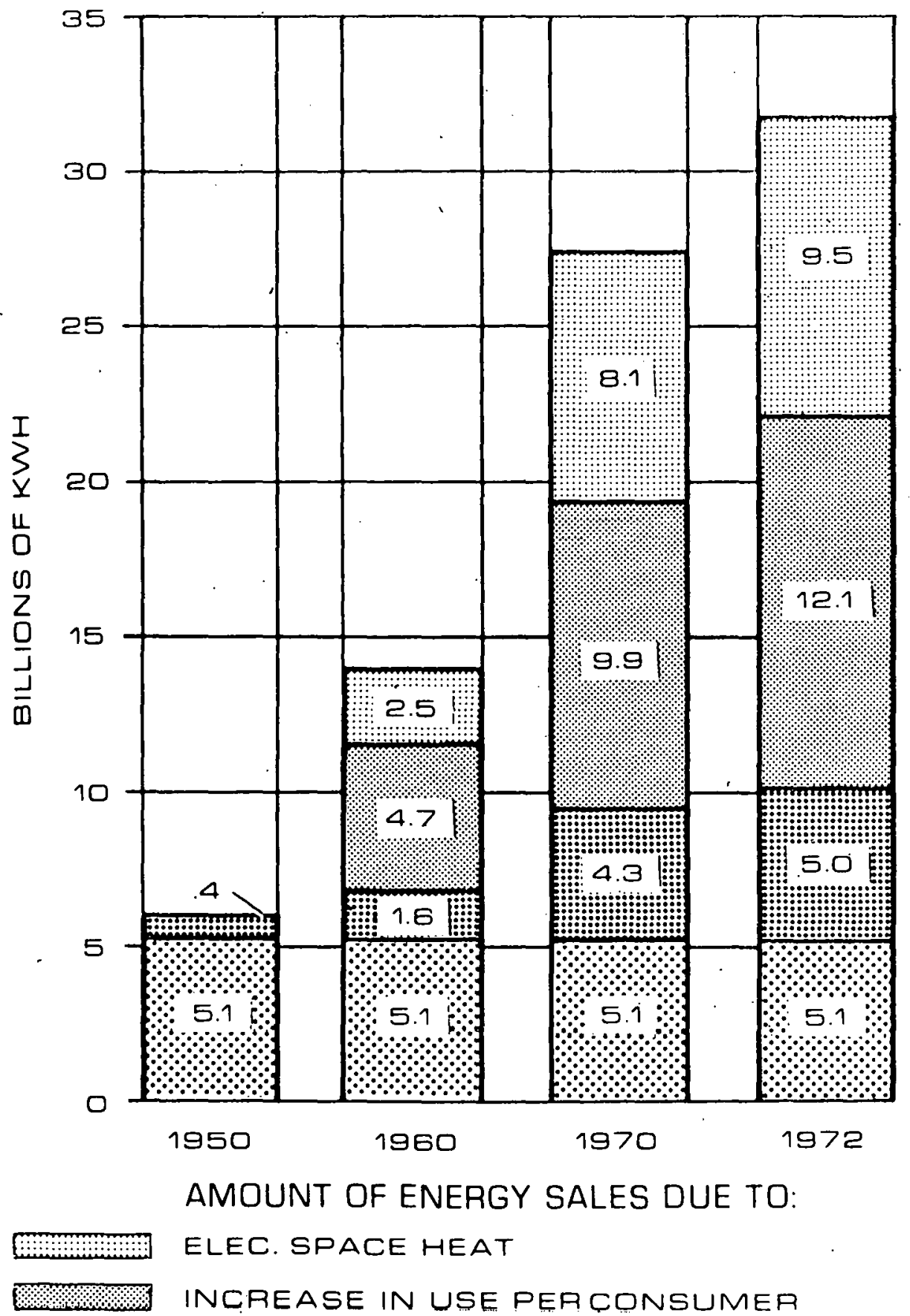

ELEC. SPACE HEAT

INCREASE IN USE PER CONSUMER

OTHER THAN ELEC. SPACE HEAT

W.!n INCREASE IN ND. OF CUSTOMERS

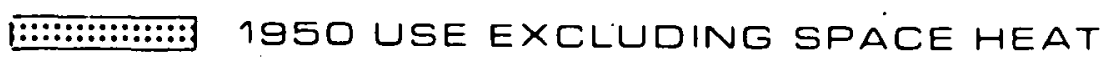

Fig. 5 (Source: Bonneyille Power Admintstration). 
TABLE I

1975 Per Capita Annual Energy Consumption

$\begin{array}{lccc} & \text { U.S. in General } & & \text { Pacific Northwest } \\ \text { Total Energy } & 4.1 \times 10^{8} \mathrm{Btu} & 3.8 \times 10^{8} \mathrm{Btu} \\ \text { Electrical Energy (a11 uses) } & 8000 \mathrm{~kW} \mathrm{hrs} & 19,000 \mathrm{~kW} \mathrm{hrs} \\ \text { Electrical tnergy (residential) } & 1500 \mathrm{~kW} \mathrm{hrs} & 5,000 \mathrm{~kW} \mathrm{hrs}\end{array}$

TABLE II

AVERAGE ANNUAL HOME ENERGY CONSUMPTION

UPFCR SNAKE RIVER VALLEY (1975)

(Idaho Falls and Typical SE Idaho Residence)

\begin{tabular}{|c|c|c|c|}
\hline \multirow{3}{*}{ Space Heating } & & Typical Cos & Btu \\
\hline & \multirow[t]{2}{*}{$120 \times 10^{6} \mathrm{Btu}$} & {$[0 i 1$} & $\$ 4.40$ \\
\hline & & $\{$ Gas & 2.20 \\
\hline Hot Water Heating & 40 & Electricity & 4.00 \\
\hline Electricity & 60 & & 5.00 \\
\hline $\begin{array}{l}\text { Gasol ine for Cars } \\
\text { (1000 gallons) }\end{array}$ & 140 & & 3.50 \\
\hline
\end{tabular}


Table III

Summary of Pertinent $\mathrm{Cl}$ imatological and Meteorological Data at the Idaho National Engineering Laboratory Basef on Weather Bureau Records from 1950 to Present

Jan Feb Mar Apr May Jun Jul Aug sep oct $\underline{\text { Nov }} \underline{\text { Dec }}$

1. Temperatures

a. Ranges

$\begin{array}{lrrrrrrrrrrrr}\text { Average Maximum } & 27.6 & 32.9 & 41.9 & 56.0 & 67.1 & 75.5 & 88.1 & 85.7 & 73.4 & 60.5 & 42.9 & 31.1 \\ \text { Average Minimum } & 3.8 & 8.2 & 18.0 & 29.0 & 38.0 & 42.6 & 50.3 & 48.1 & 38.6 & 27.3 & 17.0 & 9.1\end{array}$

b. Annual Average Temperature: $41 \pm 2^{\circ} \mathrm{F}$

2. Nominal Degree Days of Heating - 8800 (average). Extremes: 9600 in 1964; 7800 in 1958

Nominal Degree Days of Cooling - 250 (average). Extremes: 500 in 1961; 130 in 1965

3. Solar Radiation Received

(average integrated daily total) June $-620 \mathrm{cal} / \mathrm{cm}^{2}$ December $-180 \mathrm{cal} / \mathrm{cm}^{2}$ on horizontal surface

4. Wind Velocity

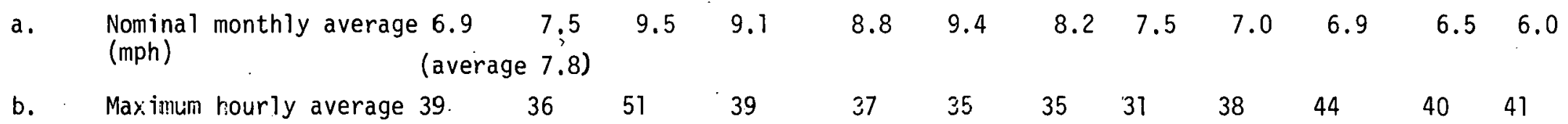

5. Average growing season - 115 days, May 20 to September 15 
Table IV

Summary of Pertinent Climatological and Meteorological Datē at Salt Lake City, Utah

Jan Feb: Mar Apr May, Jun Jul Aug sep oct $\underline{\text { Nov }} \underline{\text { Dec }}$

1. Temperatures

a. Panges

\begin{tabular}{|c|c|c|c|c|c|c|c|c|c|c|c|c|}
\hline fiverage Maximum & 36.8 & 42.0 & 52.0 & 63.4 & 74.0 & 83.7 & 94.1 & 90.8 & 80.3 & 65.2 & 47.5 & 39.0 \\
\hline Giverage Minimum & 17.5 & 22.9 & 28.8 & 36.4 & 43.8 & 51.0. & 59.6 & 58.2 & 48.5 & 38.2 & 25.9 & \\
\hline
\end{tabular}

b. Annual Average Temperature: $50.9^{\circ} \mathrm{F}$

2. Nominal Degree Day of Heating - 6052 (Average)

$\overrightarrow{0} \quad$ Nominal Degree Day of Cooling - 926 (1971)

3. Solar Râdiation Rezeived

(Averáge integrated daily tatal) June $-702 \mathrm{cal} / \mathrm{cm}^{2}$ December $-160 \mathrm{cal} / \mathrm{cm}^{2}$ on horizontal surface

4. Wind Velocity
a. Nominal monthly average 7.6
$\begin{array}{lll}8.2 & 9.1 \quad 9.4\end{array}$
9.39 .2
$9.3 \quad 9.5 \quad 9.0$
$\begin{array}{lll}8.4 & 7.7 & 7.4\end{array}$
b. Maximum hou'ly average 52
$\begin{array}{lll}56 & 71 \quad 57\end{array}$
$57 \quad 63$
$49 \quad 58$
61
$67 \quad 63$
54

5. Average growing season - 170 days, May 5 to September 25

NOTE: The climate of Boise, Idaino, one of the cities selected for further detailed analysis, approximates the climate of Salt Lake city. 
Space Heating Fuel Cost Provided by a Single Source 1975

For Total U.S.

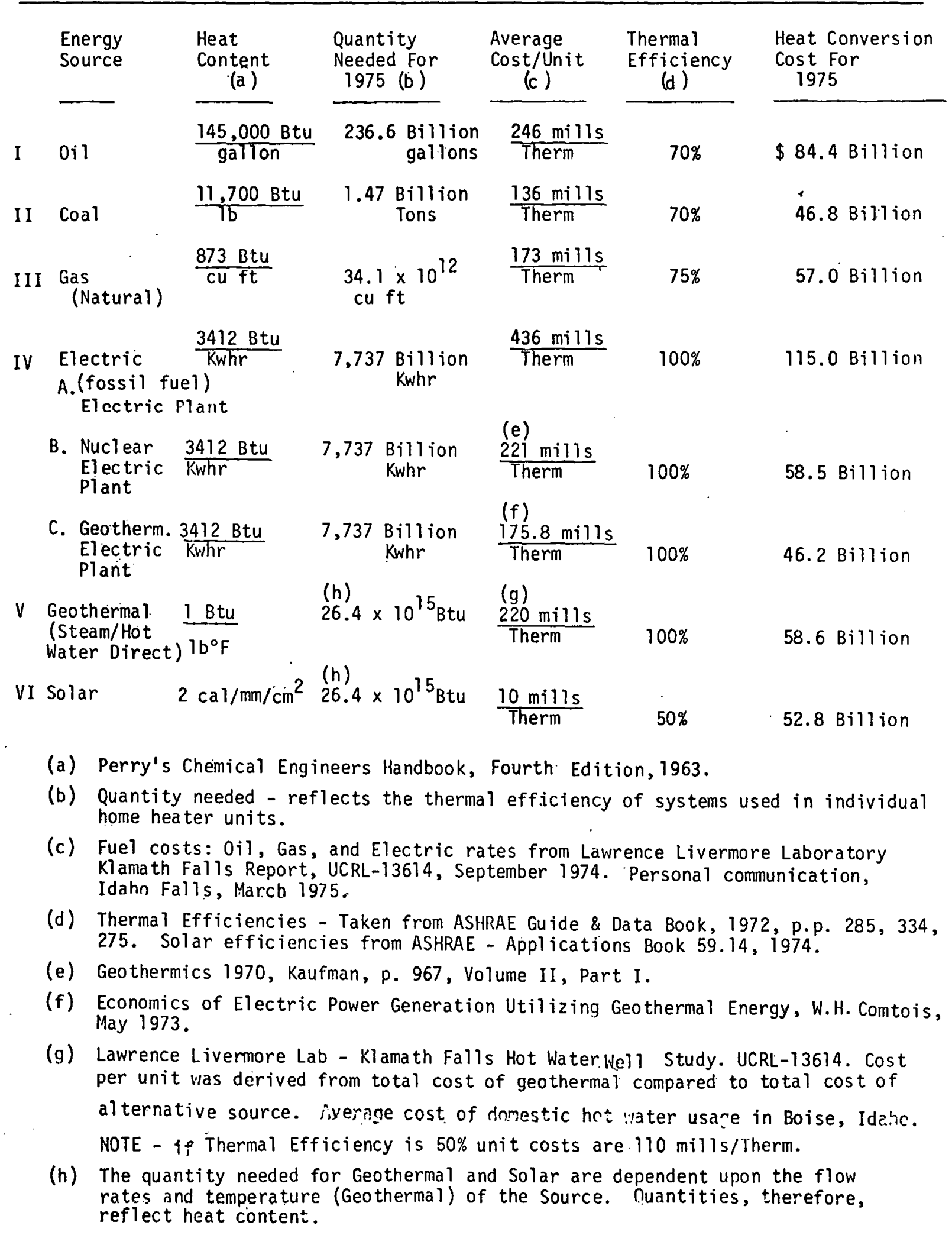


TABLE VI

\section{Space Heating Systems by Transfer Medium}

\section{District leating Plants}

A. Steam

1. Nuclear - with heat exchanger

2. Boiler - coal, gas, oil or geothermal preheat

3. Geothemal - direct or with heat exchanger

- (types of final delivery listed under individual units.)

B. Hot water
1. Hirlear = with heat exshanger and pump assisted
2. Boiler - coal, gas, oit or electric
3. Geothemal - direct or with heat exchanger
1. Usc of hout pumps to assist the abuve
5. types of final delivery listed under individual units.

C. ETectric

1. Power Plants as a District Heating Sy'stem -0il, Coal, Gas, Nuclear,

2. Individual complex heating systems (apartments, schools, etc.)

A. Steam

1. Central boiler - coil, gas, oil, or genthermal preheat

2. Geothermal - direct or with heat exchanger

3. Heat pumps

4. Types of terminal devices listed under individual unit.s

B. Hot Water
1. Boiler - coal, gas, oil, electric
2. Geothermal - direct or with heat exchanger
3. Hieat pump assisted
4. Electrically heated
5. types to be listed under individual units
6. Solar conversion

C. Hot air

1. Furnace - gas, coal, or oil

2. Water/air or steam/air heat exchangers

The watur or stean provlded by boller or geothermal source

3. Types of terminal devices listed under individual units

4. Solar Conversion

3. Individual heating systems.

A. Steam
1. Buller - gas, coal, oil, or geothermal preheat
2. Geothermal - direct or with heat exchanger
3. Heat punps
4. Types of steam systems:
Two pipe system - (gravity or mechanical return)
Vapor systeills
Vacuuill systeins
Subatmospheric systems Mechanical system
Two pipe orifice system 
5. Types of terminal devices

Radiators and condictors, baseboard and finned tube radi-

tion unit ventilators, unit heaters, fan-coil units, central air handling urits.

B. Hot water systems

1. Boiler - coal, gas, oil, electric

2. Geothermal.- direct or with heat exchanger

3. Heat pumps

4. Solar

5. Types of hot water systems

Low temperature $\left(160 \mathrm{psig}, 250^{\circ} \mathrm{F}\right)$

Series loop system

one pipe (diverting fitting) system

two pipe system

combination systems

Medium and High Temperature Systems

saturated steam cushion systems gas or pump pressurized systems

6. Types of terminal devices
Viatural convection units - cast iron radiators, cabinet convectors, baseboard and finried tube radiation
Forced convection units - unit heaters, unit ventilators, fan-coil units, induction units, air handling units
Radiation
- panel systems, unit radiant panels.

C. Hot Air Systems

i. Types of systems

Single 7one System

Variable volume air systems (VAV)

VAV reheat or VAV dual duct

VAV with independent air or hydronic perimeter systen

VAV with constant zore volume

pulsating zone VAV. with constant system volume

Reheat system

primary air constant volume reheat system

induction type reheat

low temperature reheat induction

variuble volume reheat

Dual duct systems

Multizone systems

Ceiling induction systems

perimeter. loop heating system

2. Solar Systemis

perimeter radial systems

D. Eiectric Systems

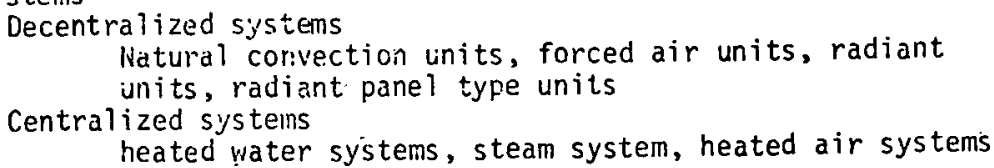

[. Tota? chergy systems

$F$. Heat recovery systems

G. Remute units

H. Space heaters. 


\subsection{SPACE HEATING REQUIREMENTS}

Factors which affect the space heating requirements of buildings and which are considered in this report are climate, population density and system type.

Climatic factors constitute the majority of design requirements for any space heating equipment. Four locations, each with different climatic conditions, were chosen for calculation of heating loads and design factors. The cost analysis of space heating systems was based upon these heating requirements and thus the selection of locations was chosen to cover a wide range of climatic conditions.

The four locations selected were: 1) Boise, Idaho, where a current ERDA-State of Idaho Demonstration Geqthermal Project is being investigated and conducted; 2) Pendelton, Oregon 2 with semi-arid climate and hot sunny summers; 3) San Francisco, California, with a cool coastal cl imate, and 4) Idaho Falls, Idaho, with a dry climate, severe winter conditions, and cool summers,

Ten-year average values for degree-days were taken from American Society of Heating, Refrigerating and Air Conditioning Engineers, Inc. (ASHRAE) with a $65^{\circ} \mathrm{F}$ base $(3)$. Attempts were made to show the effects of solar radiation, relative humidity and wind speed for each of the locations selected. investigated.

The heating requirements of the following types of buildings were

1. Apartments

2. Residential houses

3. Shopping - Office buildings

4. Industrial buildings

Apartments

The apartments considered are of $8400 \mathrm{sq} \mathrm{ft}$ per story and 3 stores high. Total enclosed area therefore, is 25,200. sq ft, or 201,600 cubic $\mathrm{ft}$ for $8 \mathrm{ft}$ ceilings.

\section{Residential Houses}

The residential area is made up of individual houses each of $1800 \mathrm{sq} \mathrm{ft}$ or 14,400 cubic ft per building.

Shopping - Office

An office building or local shopping building is considered to be of $.25,300 \mathrm{sq} f \mathrm{ft}$ or 202,400 cubic $\mathrm{ft}$. 


\section{Industrial Buildings.}

The industrial bulldings are of large area, 200,000 sq ft or 2,000,000 cubic ft with $10 \mathrm{ft}$ ceilings.

(The heat losses of these buildings were estimated by the degree day method ${ }^{(4)}$ with $65 \mathrm{~F}$ as the base temperature. The hourly heat loss was estimated using the methods described in the Handbook of Air Conditioning, Heating and Venting (3).

The seasonal heat loss was estimated from the equation:

$$
\begin{aligned}
& H=\frac{24 h d\left(t_{1}-t_{a}\right)}{t_{1}-t_{0}} \\
& H=\text { Seasonal Heat Loss } \\
& h=\text { Hourly Heat Loss } \\
& d=\text { Number of Heating Days } \\
& t_{1}=\text { Design Temperature Inside }\left(65^{\circ} \mathrm{F}\right) \\
& t_{0}=\text { Design Temperature Outside } \\
& t_{a}=\text { Average Outside Temperature } \\
& K=\frac{H}{h D} \cdot 1000, D=\text { degree days/yr }
\end{aligned}
$$

The following data taken from ASHRAE - Fundamentals were used to calculate the seasonal heat loss $(4)$.

Idaho Falls, Pendelton, Oregon S.F.,Calif. Boise, ID

$\begin{array}{llccc}\text { Normal Degree Days } & 8900 & 5204 & 3421 & 5890 \\ \text { Winter Design Temperature } & -15^{\circ} \mathrm{F} & +15^{\circ} \mathrm{F} & +30^{\circ} \mathrm{F} & -10^{\circ} \mathrm{F} \\ \text { Heating Days Per Season } & 320 & 260 & 365 & 277 \\ \text { Average Winter Temperature } & 34.9^{\circ} \cdot \mathrm{F} & 45.0^{\circ} \mathrm{F} & 55.6^{\circ} \mathrm{F} & 43.7^{\circ} \mathrm{F} \\ \mathrm{K} \quad(4)^{\circ} & 350 & 352.7 & 1053.1 & 370.5\end{array}$

The last line, $K$, is a measure of the relative effectiveness of butlding design and construction in reducing heat loss. It represents average heat transfer for the building exterior. 
Hourly heat loss per building type for the four locations chosen. is given below in Btu/hr:

\begin{tabular}{rrrr} 
Idaho Falls, & Pendelton & -San Francisco & Boise \\
\hline $1,330,560$ & 860,000 & 630,000 & $1,270,000$ \\
95,760 & 61,920 & 44,640 & 88,200 \\
$1,275,120$ & 820,000 & 610,000 & $1,190,000$ \\
$13,000,000$ & $8,200,000$ & $5,800,000$ & $12,200,000$
\end{tabular}

Substituting the hourly heat loss into Equation 1, the following seasonal heat losses were calculated (Btu/yr).

Apartments

Residential

Shopping

Industrial

\section{Inaho Falls}

$$
4,144 \times 10^{6}
$$

$298.3 \times 10^{6}$

Residential

Shopping

Industrial
$3,971.9 \times 10^{6}$

$40,495 \times 10^{6}$

\section{Pendelton}

$1,578 \times 10^{6}$

$113.6 \times 10^{6}$

$1,505 \times 10^{6}$

$15,050 \times 10^{6}$
San Francisco

Boise

$2,269 \times 10^{6}$

$160.8 \times 10^{6}$

$2,197.6 \times 10^{6}$

$20,895 \times 10^{6}$
$2,771.5 \times 10^{6}$

$192.5 \times 10^{6}$

$2,596.8 \times 10^{6}$

$26,623 \times 10^{6}$

The following block diagram has been used in calculation of the annual cost of a particular system to supply the heating demand.

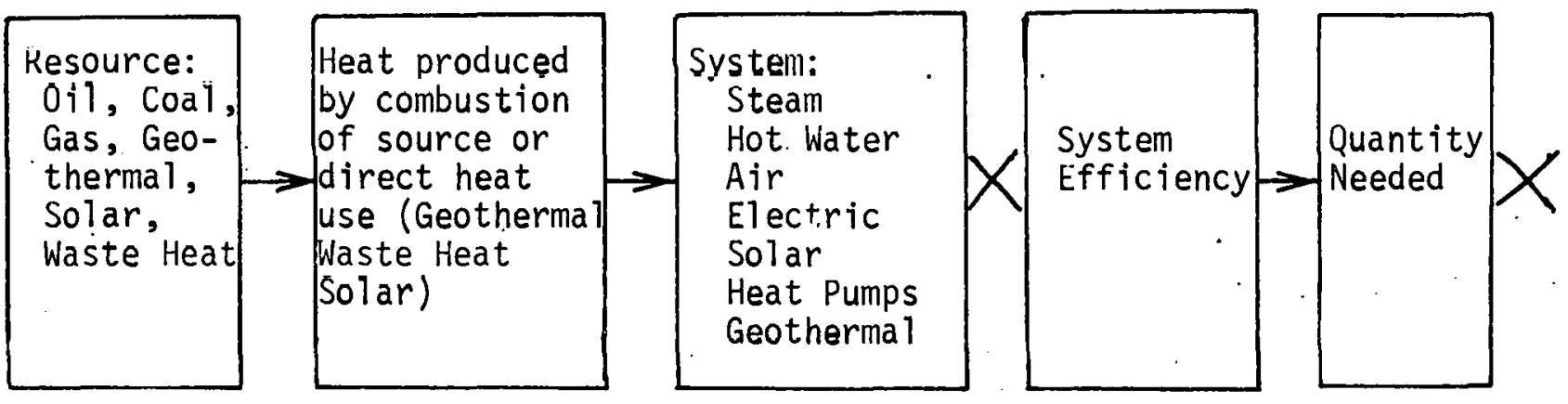

\begin{tabular}{|c|c|c|c|c|}
\hline $\begin{array}{l}\text { Unit } \\
\text { Cost } \\
\text { of } \\
\text { Source }\end{array}$ & $\begin{array}{l}\text { Total } \\
\text { Annual. } \\
\text { Heat ing } \\
\text { Fuel } \\
\text { Cost }\end{array}$ & + & $\begin{array}{l}\text { Total } \\
\text { Annual } \\
\text { Proportion } \\
\text { of Initial } \\
\text { Cost and } \\
\text { Maintenance } \\
\text { Cost }\end{array}$ & $\begin{array}{l}\text { Total } \\
\text { Annual } \\
\text { Heating } \\
\text { Cost per } \\
\text { System } \\
\text { Type.per } \\
\text { Locality }\end{array}$ \\
\hline
\end{tabular}




\subsection{HEATING SYSTEMS}

\subsection{Total Air Systems}

An Air System includes various distribution networks to supply heat by a hot air medium(5).

Air systems may be classified into the categories of: 1) single path systems and 2) dual path systems. The single path system utilizes a common duct system in series to provide heat to all terminal devices. The dual path system consists of the variable air volume (VAV) and multizone systems. Air systems have the advantage of being centrally located thus easing maintenance and providing a flexible system.

The American Gas Association certifies forced air gas furnaces at a rating based on $80 \%$ efficiency. 0 il fired furnaces. equipped with pressureatomizing or rotary burners require a minimum efficiency of $80 \%$ for forced air furnaces. Furnaces equipped with pot-type oil burners require a minimum efficiency of $70 \%$. 6 )

\subsection{Steam and Water Systems}

Radiators, convectors, baseboard, and finned tube terminal devices are used in both steam and hot water systems. Small and jarge tube cast iron radiators emit 240 Btu per hour per square foot of exposed area 6 .

$$
\begin{aligned}
& 240 \text { Btuh = } 1 \mathrm{sq} \mathrm{ft} \text { EDR (equivalent direct radiation) } \\
& \text { with } 1 \text { psig steam }
\end{aligned}
$$

Tables are available for converting steam ratings to hot water ratings at various temperatures. Water systems will be analyzed here for a temperature of $180^{\circ} \mathrm{F}$ at which a factor of 169 is used to determine water ratings from steam ratings. The Packaged Firetube Branch of the American Boiler Manufacturers Association conducted tests used by its member companies resulting in efficiency ratings of not less than $80 \%$ when burning 017 and not less than $75 \%$ when burning gas to fire boilers $(7)$ ASHRAE Guide and Data Book $(6)$ produces the following efficiencies:

$\begin{array}{ll}\text { Anthracite, hand fired } & 60-70 \% \\ \text { Bituminous coal, hand fired } & 50-65 \% \\ \text { Stoker fired } & 60-75 \% \\ \text { 0il and Gas Fired } & 70-80 \% \\ \text { Electric } & 90-99 \%\end{array}$

The above are those used in steady state operation and are thus higher than those obtained in actual service. The steam or hot water once distributed through the terminal devices is returned to the boiler. The heat extracted from the heat medium will be assumed equal to that gained by the air. 


\subsection{Heat Pump Use}

Commercial heat pumps generally resemble commercial air conditioning systems. The thermodynamic cycle is the same, except that for heating, the outside coil becomes the evaporator, the inside coil the condenser. Most heat pumps have a four way valve to switch the roles of the inside and outside coils and hence provide either heating or cooling as the need exists.

Heat output in Btu's is generally 2-3 times larger than the heat input when using a heat pump (typical 2 at $32^{\mathrm{F}}, 3$ at $50^{\circ} \mathrm{F}$ ). However, at about $0^{\circ} \mathrm{F}$ most current commercial heat pumps reach a coefficient of performance (COP) of unity. For the Northwest's "average" climate, a coefficient of performance of 2.06 has assigned to the utilization of heat pumps. Because of the drop in efficiency with temperature drop, heat pump installation is not designed to provide the full heat load on the coldest of days. For this reason, supplementary heat is usually supplied in areas where temperature entraces are large. Heat pumps, although in commercial and residential operation for well over 20 years, have remained generally localized in application. Only recently has emphasis on consumer marketing been revived by the principal manufacturers, particularly in the colder northern climates where they had seen little previous use.

Several sources are available as a heat source for heat pumps during the heating season and include the following: air, city water, well water, surface water, waste water, earth and solar sources. The heat source is used to supply heat to the conditioned space, the heat sink. Principal mass produced commercial units for single residents $(20,000$ to $50,000 \mathrm{Btu} / \mathrm{hr})$ use air as the source, and thus are adversely affected by extremely cold (approximately $0 \mathrm{~F}$ or below) winter temperatures. Many large commercial systems have been built to utilize water as the heat source, and hence show virtually constant coefficient performance (COP) throughout the year of about 3 or larger. Despite earlier poor reports on reliability, recent analys is by electric utilities on heat pump usage in their service areas show typical failure rates of 3 to $4 \%$ annually, nearly constant throughout the first 20 years of service.

The use of water "cooled" heat pumps (with typical source temperatures of $50^{\circ}$ to $60^{\circ} \mathrm{F}$ ) seems to offer considerable attraction where adequate water supplies are available. Extracting heat equivalent to a $10 \% \mathrm{~F}$ drop in temperature of the water gives a requirement of 5 gallons/minute for a typical residence on a $-20 \mathrm{~F}$ day. Thus the water usage is not unrealistic, and it can be non-consumptive by returning the water to its source. Figure 6 shows a typical example of the advantage to be gained by a heat pump compared to electric resistance heating, for instance.

Heat pump applications have two other intrinsic advantages.

1. Compared to $0 i 1$ and gas furnaces operating at $70 \%$ efficiency, a heat pump supplied by a fossil-fueled electric generating plant will usually consume less fossil fuel than an oil or gas furnace. The latter typically have $70 \%$ efficiency, and new fossil-fueled electric generating plants have $40 \%$ efficiency. Thus, any heat pump exceeding a COP of -1.75 is more conserving of fuel than the direct burning of the fuel. 


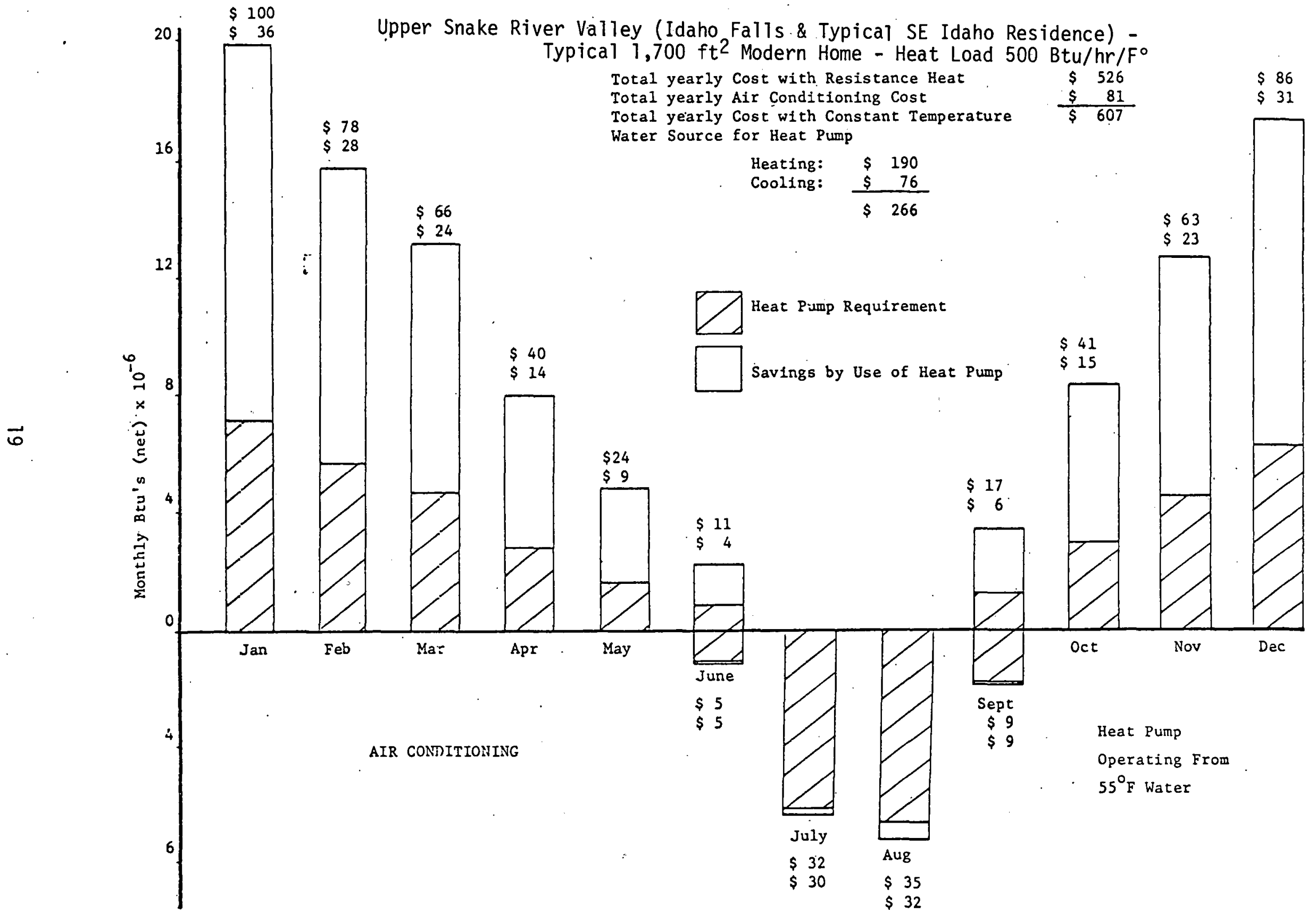

Fig. 6 
2. Heat pumps will require the greatest use during the cold night-time hours when utility demands are at the minimum. Thus, electric utilities highly favor the use of heat pumps for space heating.

\subsection{Electric Systems}

Electric systems are generally suitable for a number of space heating applications owing to their ease of distribution, control, simplicity, and cleanliness. Compared to fossil fuel types, an electric system is more efficient and effective. An electric heating unit consists of a frame or casing to support one or more heating elements. The principal types of electric heating systems are either centralized or decentralized systems, with the former utilizing electricity to heat water or air as described under air and steam systems. The coefficient of performance of electric heating systems is 1.00 or $100 \%$.

\subsection{Geothermal Space Heating Systems}

Geothermal systems vary according to the salinity, chemical analysis, temperature and flow rate of the water used. Two cases have been considered here:

1. The geothermal water is low enough in salinity that a direct water distribution system may be used.

2. The geothermal water is hot enough to allow the use of a heat exchanger.

The distribution network in either case approximates that of a steam or hot water heating system. Geothermal prices are dependent upon proximity to local sources.

3.6 Solar Heating Systems

Solar energy is received in sufficjent quantities to make a major contribution to U.S. heat and power needs (8). The following inherent characteristics of solar radiation limits its use at present.

1. Solar radiation is low in intensity

2. Solar radiation is intermittent due to variations of the solar angle

3. Solar radiation received at earth is variable, owing to clouds, rain, snow, and various other climatic conditions.

The solar constant is 2 calories $/ \mathrm{min} / \mathrm{cm}^{2}$ for direct incident sunlight. However, this value is substantially reduced by the above listed three conditions. Solar radiation for space heating can be used by two processes: 1) helioelectrical and 2) hel iothermal. The former through convectors, changes the radiation into electrical energy. This method is extremely. expensive and impractical for consideration of space heating. The latter method is a conversion process from solar to heat energy. This method is direct, workable, and technically quite practical. (It's current high cost is discussed below.) 
The flat-plate collector is simply a back-insulated, radiationabsorbing surface warmed by the sun's rays and, if the desired temperature justifies it, protected against too rapid loss of energy due to backradiation and connection by being covered with one or more solar-transparent but long wave-opaque layers of glass or plastic (9). Improvements on solar transmittance have greatly increased the efficiency of solar collectors.

The efficiency of a well-constructed and properly-designed thermosyphon water heater will range from $45-65 \%(10)$. The efficiencies of forcedcirculation air heaters will vary hourly due to changes in incident angles.

The monthly degree days for each of the cities considered in this report provide a method for calculation of the annual heating load. A suitable percentage of this load handled by a solar heating system will optimize its utilization leaving days of low solar radiation and/or high heat loss days to be handled by a supplemental heating system. The following are average solar radiation amounts recelved on a horizontal surface during the heating season:

$\begin{array}{ll}\text { San Francisco } & 1343 \mathrm{Btu} / \mathrm{sq} \mathrm{ft} / \mathrm{day} \\ \text { Pendelton } & 1317 \mathrm{Btu} / \mathrm{sq} \mathrm{ft} / \mathrm{day} \\ \text { Boise and Idaho Falls } & 1376 \mathrm{Btu} / \mathrm{sq} \mathrm{ft/day}\end{array}$

Assuming that sufficient surface area is present, the solar system analyzed for economical consideration in this report will provide $30 \%, 50 \%$, or $70 \%$ of the total heating load. All of these systems will require some type of storage to provide the needed energy overnight. The $70 \%$ system will need more than overnight storages. Supplemental heat must be supplied to fulfill the additional requirements, and must be designed to carry $100 \%$ of full load during low solar radiation periods and/or high heat loss days.

Many solar houses have been built, demonstrating an average $80 \%$ efficiency rate $(11,12, \& 9)$. Thus for the time that the solar system is on-1ine, $80 \%$ will be used in this report for the efficiency of a solar heating system. (This is in addition to the 30,50 , or $70 \%$ values for "on-l ine" time.)

The above values are considered average for a moderate climate. However, for the extreme winter conditions of the high mountain plateaus of the Northwest, solar heating systems of typical design (single or double pane) are essentially out-of-service (or useless) during much of December and virtually all of January. Though for a few hours on a bright sunny day (sunny days are usually the coldest days at that time of year) the system may reach sufflctent temperature to be operable, it will be supplying a virtually. infinitesimal fraction of the energy needs during those two months. Figure 7 shows a typical analysis for the Idaho Falls area, which is the most severe of the four example cities considered. For this reason, neither the $50 \%$ or $70 \%$ solar systems are considered as reasonable or practical for Idaho Falls. Similarly, the $70 \%$ system is considered impractical for Boise or Pendelton. 


\section{SOLAR HEAT SYSTEWI}

- $1000 \mathrm{ft}^{2}$ INSTALLATION -TYPICAL $1700 \mathrm{ft}^{2}$ MODERN HOME - UPFER SNAKE RIVER VALLEY OHEAT LOAD $500 \mathrm{Btu} / \mathrm{hr} /{ }^{\circ} \mathrm{F}$

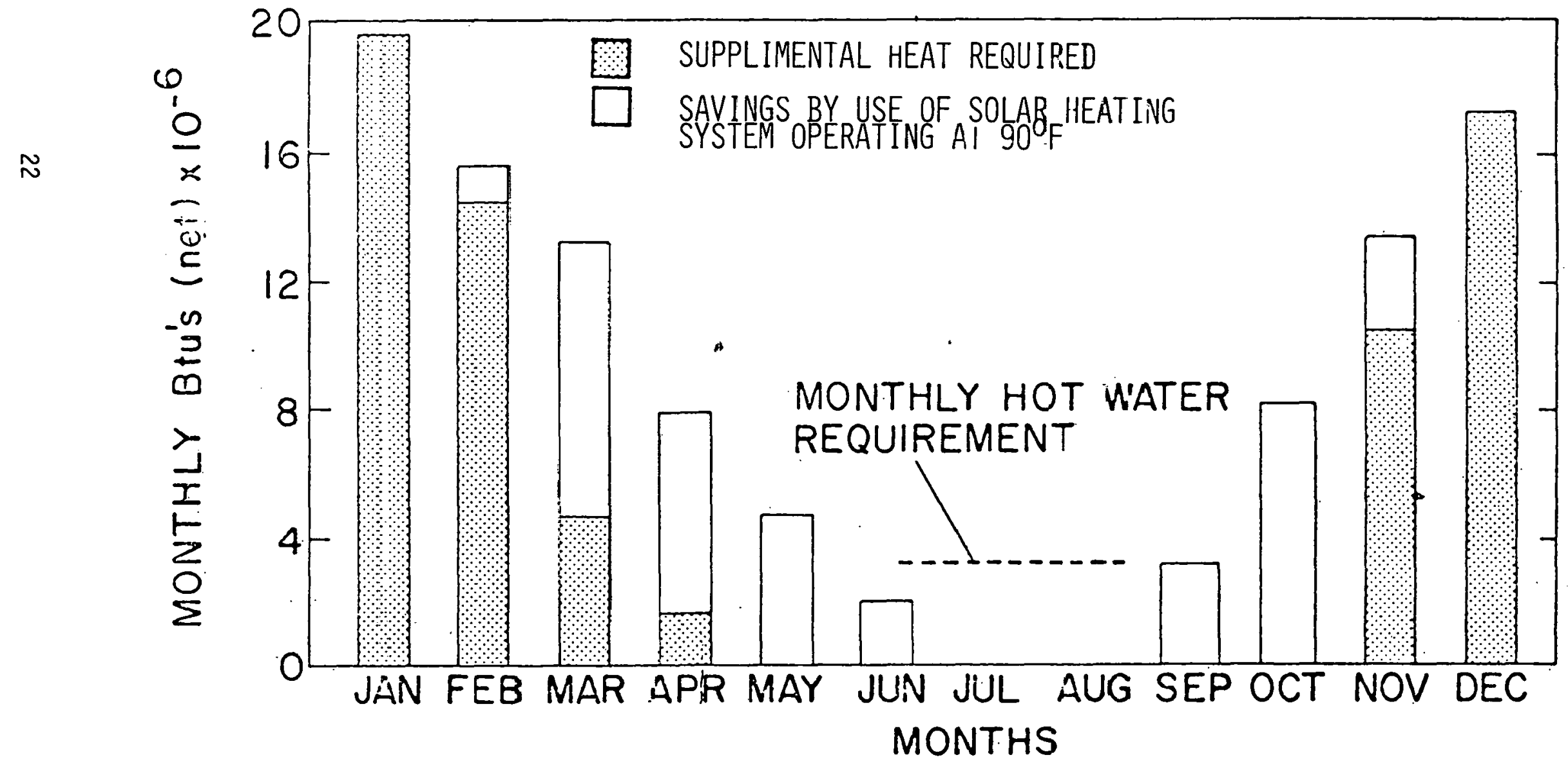

Fig. 7 
Capital costs are roughly calculated for these systems. $\$ 4 / \mathrm{ft}^{2}$ for single pane and $\$ 7 / \mathrm{ft}^{2}$ for double pane systems are considered typical. Overnight storage systems, either air or water, are likely to cost $\$ 1,000$ to $\$ 3,000$, depending on the location and type of system (rock or water). The interior heat distribution systems will generally cost more than for the conventional fossil-fueled heating systems, because the solar device should be able to work at lower effective temperatures in order to increase its on-line time capability.

\subsection{Waste Heat Systems}

Waste Heat Systems are those in which waste power plant heat is utilized to provide heating through a normal steam space heating distribution network. The first costs of the distribution network have been estimated as equivalent to those accrued by a steam heating system.

It will be assumed that power plant waste heat is available through a district piping system.

\subsection{Hybrid Solar - Heat Pump System}

In cold climates where the air exchange heat pump suffers from poor coefficient of performance and conventional solar heating systems are ineffective in winter, a hybrid system may have potential. The performance of the heat pump can be enhanced by raising its source temperature moderately 1.e., such as from $-10 \mathrm{~F}$ to $30 \mathrm{~F}$, thus doubling its cog. A solar collector. system would thus need to work only in the range of $30^{\circ} \mathrm{F}$ instead of approximately $100^{\circ} \mathrm{F}$, required for direct solar heating. The difference could be quite significant in terms of the on-line time of the solar heating system, since it can enhance the heat pump regardless of the temperature outside. The largest gains will be affected on the coldest days, with present commercial heat pump systems. During days of moderate temperature ( $30^{\circ}$ to $50 \mathrm{~F}$ ), enhancement is 1 ikely to occur to temperatures above $80 \mathrm{~F}$, beyond which point gains in COP are minimal, and often turn negative. Figure 8 shows the type of improvement that might be expected with the use of a relatively small solar collection system. Use of different working fluids and perhaps multistaging of the compressor units would better adapt heat pumps to these extremes of temperature.

The types of hybrid systems that could be used are several, and detailed analysis of each is needed before definitive answers can be given. For this reason, the hybrid solar-heat pump system is not dealt with in the tables that follow.

\subsection{Wind Energy}

Windmills for producing electricity have received considerable attention of late. Their problem is one of cost, partly in the cost of switch gear, frequency control and/or battery storage. However, the direct input of the electrical energy into heating coils (in an electric furnace, for instance) would require no switchgear control mechanisms, and would enable one to utilize all the available windmill energy at those times of the year when furnace heat or hot water heat is needed. The advantage is greatest for the coldest climates. 


\section{HEAT PUMP SYSTEM}

$400 \mathrm{ft}^{2}$ INSTALLATION UPPER SNAKE RIVER VALLEY
TYPICAL $1700 \mathrm{fq}^{2}$ MODERN HOME HEAT LOAC $500 \mathrm{Btu} / \mathrm{hr} /{ }^{\circ} \mathrm{F}$

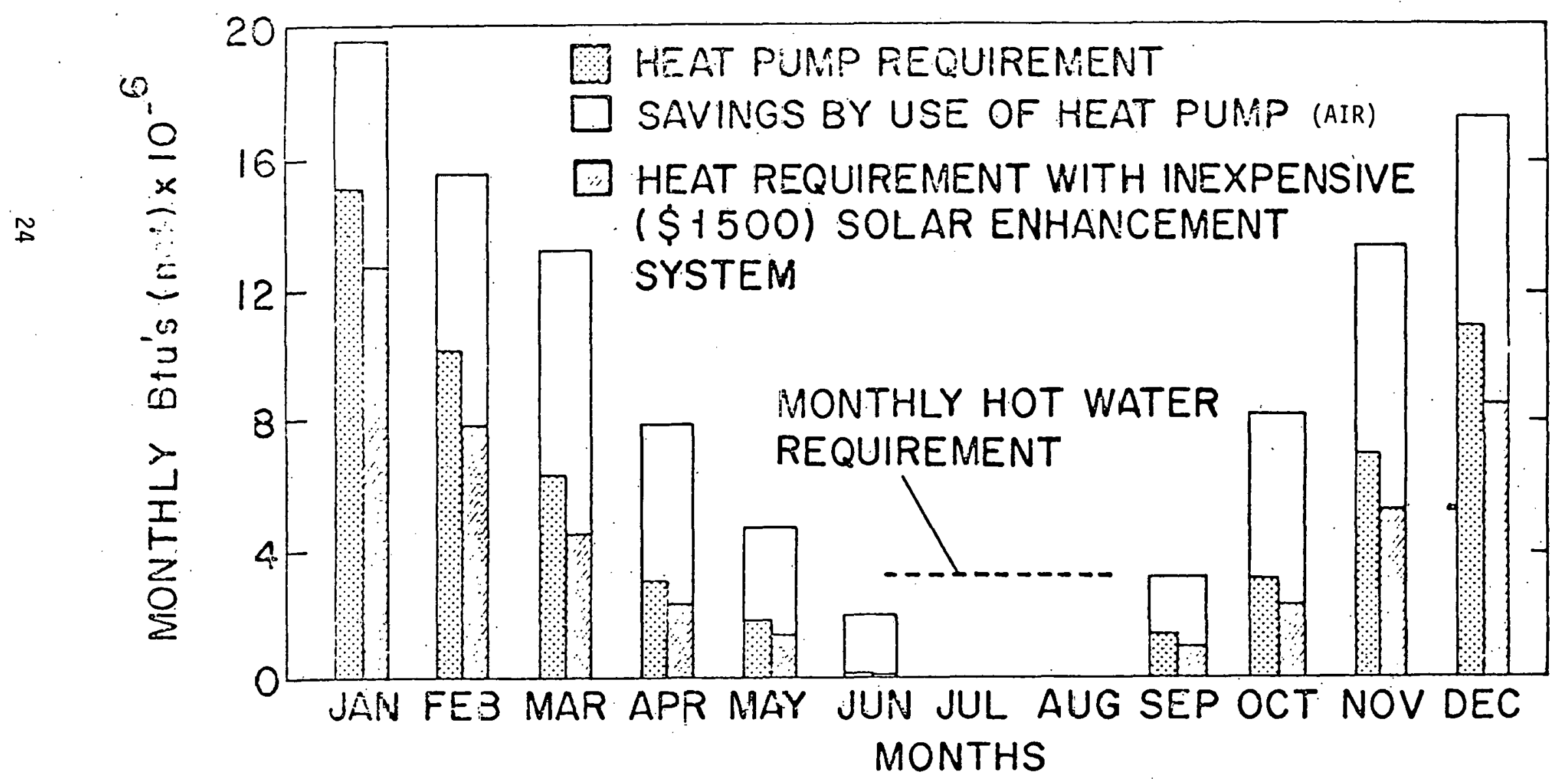

Fig. 8 
This concept has not been analyzed in detail for costs, and hence is not included in the subsequent tables. However, current capital costs of commercialiy produced windmills make these systems even more expensive than solar installations, and hence the need for including them at this state-of-development does not appear important. 


\subsection{FUEL COSTS}

Fuel costs used to estimate the annual heating costs are, for the 1975 listing, those actually being charged in the Idaho Falls area for 1975. These are considered typical for the entire Northwest. The projections into future years were derived from the 1970 National Power Survey Part I (13) The Federal Power Commission estimated that fuel oil and coal will increase 2.27 percent per year during the 1968-1990 period (uninflated). Natural gas rates are estimated by the Federal Power Commission to increase 4.55 percent per year (uninflated) between the 1968 to 1990 period. The commission also estimated an increase of 1.22 percent per year (uninflated) for electricity during the same period.* Present fuel costs were estimated by conversations and rate schedules of local companies (Idaho) and projected to 1985 using the yearly percentage increases as given by the Federal Power Comission. Table VII lists residential fuel rates unless specified otherwise.

The annual consumption rate of fuels for heating is a function. of both the heating system type used and the fuel type used. Fuel oll, for example, could be utilized to heat water and thereby produce hot water/steam for use in a hot water/steam heating system or be used in a total air heating system. In each case a different quantity of fuel oil would be consumed owing to various heating systems efficiency rates. Table VIII presents the quantity of fuel consumed (per $h r{ }_{F}$ ) as a function of resource and heating system type used. Selection of the resource and heating system type to be utilized gives the fuel consumptive rate for the size of bulldings under consideration. Table VIII also lists the life expectancy of the various space heating systems.

Those systems which are hot air circulation also have an annual electrical cost due to expenditures of energy in running fans and circulation pumps. To this end, additional quantities are needed, although relatively, sma 11, and have been estimated at $703 \mathrm{kWh} / 1000 \mathrm{sq} \mathrm{ft}$ floor area annually (2). Referring back to the caluclations of annual heating requirements, Table VIII can be utilized to formulate the annual fuel consumption. This number, when multiplied by fuel cost presented in Table VII provides the yearly fuel cost associated with heating systems. Tables IX, X, XI, and XII list the yearly fuel costs of Pendelton, San Francisco, Boise, and Idaho Falls, respectively.

* Needless to say, the referenced report did not anticipate the dramatic step function that occurred in 1974 in oil costs, with many other forms of energy following competitively. It is impossibile to anticipate future political situations which may severely perturb the Federal Power Commission estimates of orderly fuel cost escalation. 
TABLE VII

Present and Predicted Residential Fuel Costs

$\underline{1975}$

$\underline{1980}$

$\underline{1985}$

Electricity

(Residential)a

$\$ 4.78 / \mathrm{MBtu}$

$\$ 5.54 / \mathrm{MBtu}$

$\$ 6.42 / \mathrm{MBtu}$

(Infustrial)b

2.69

2.97

3.28

Natural Gas (a

2.91

4.19

6.03

Fuel $0 i 1$ (ab

2.48

3.20

4.13

Coal (a

1.62

2.08

2.66

Waste Heat(c

2.87

3.71

4.80

Geotherma 1 Water(d

1.75

1.93

2.12

a Federal Power Commission, National Power Survey, 1970 updated to 1975 $\$ 4.78 / \mathrm{MBtu}$

b Idaho electric companies, Idaho oil companies, personal communications

c A System Analysis of the Economic Utilization of Warm Water Discharge from Power Generating Stations, Oregon State University Report, 1974. Heat Available from Power Plants (Coal, Nuclear).

d Boise, Warm Springs Avenue, \$1.75, July 1975 


\section{TABLE VIII}

RESOURCE QUANTITIES NEEDED IIER HK ${ }^{\circ} \mathrm{F}$ AS A FUNCTION OF HEATING SYSTEM TYPE AND RESOURCE USED

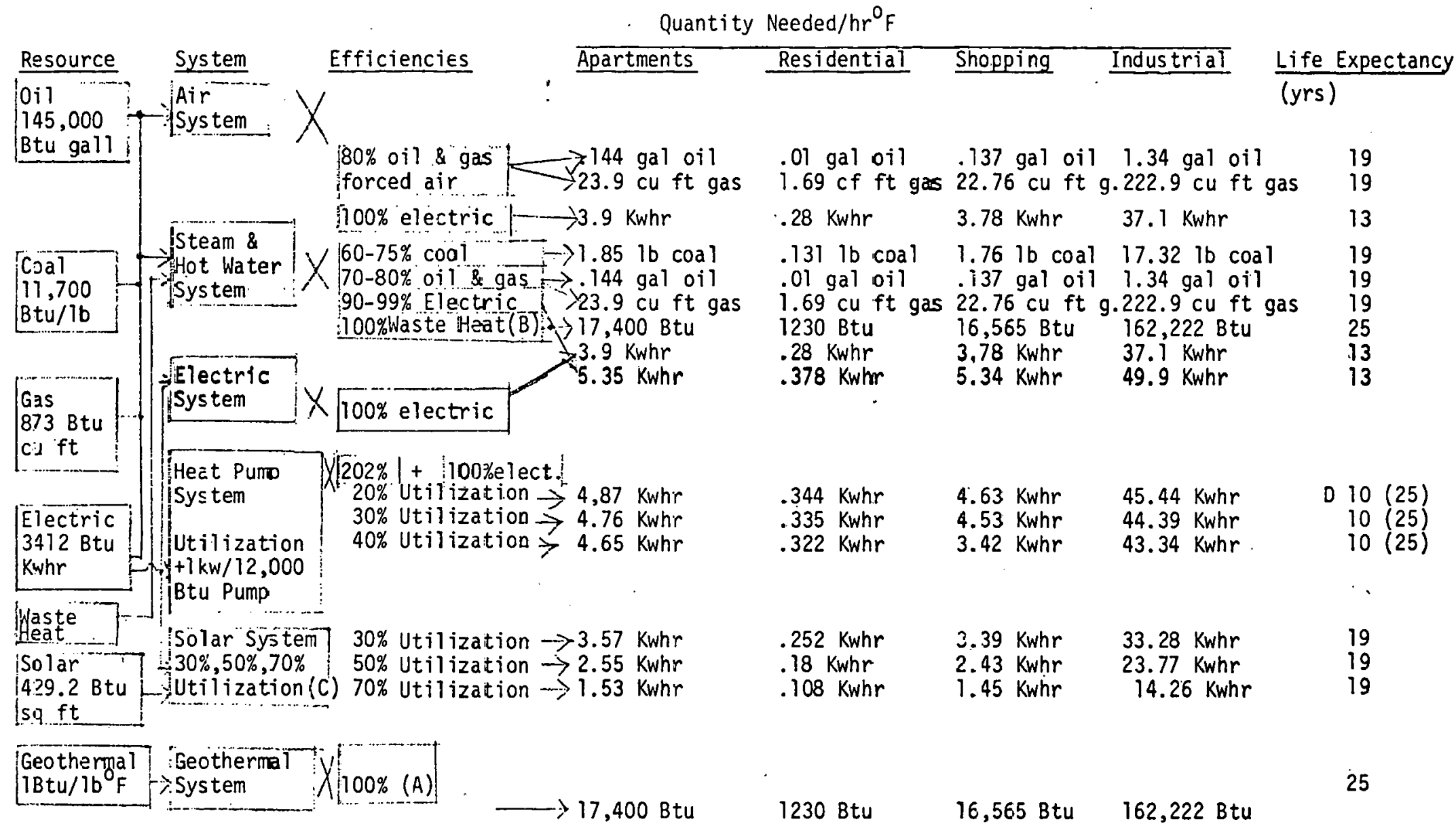

(A) Varying perceitage efficiency depending on final use of waste water:

(B) Steara from a 'Power plant susplied to a residence Waste steam is cycled in a cl-osed system.

(C) Solar System supplemented by an electric system 30,50 or $70 \%$ or annual requirements.

(D) 10 years is considered the.zaverage life of the heat pump compressor and cutside coil unit, which represents about $40 \%$ of the cost of the entire system. The rest of the system should lave a life of 25 years. 
TABLE IX

Annual Fuel Cost - Pendelton, Oregon (Dollars/Year)

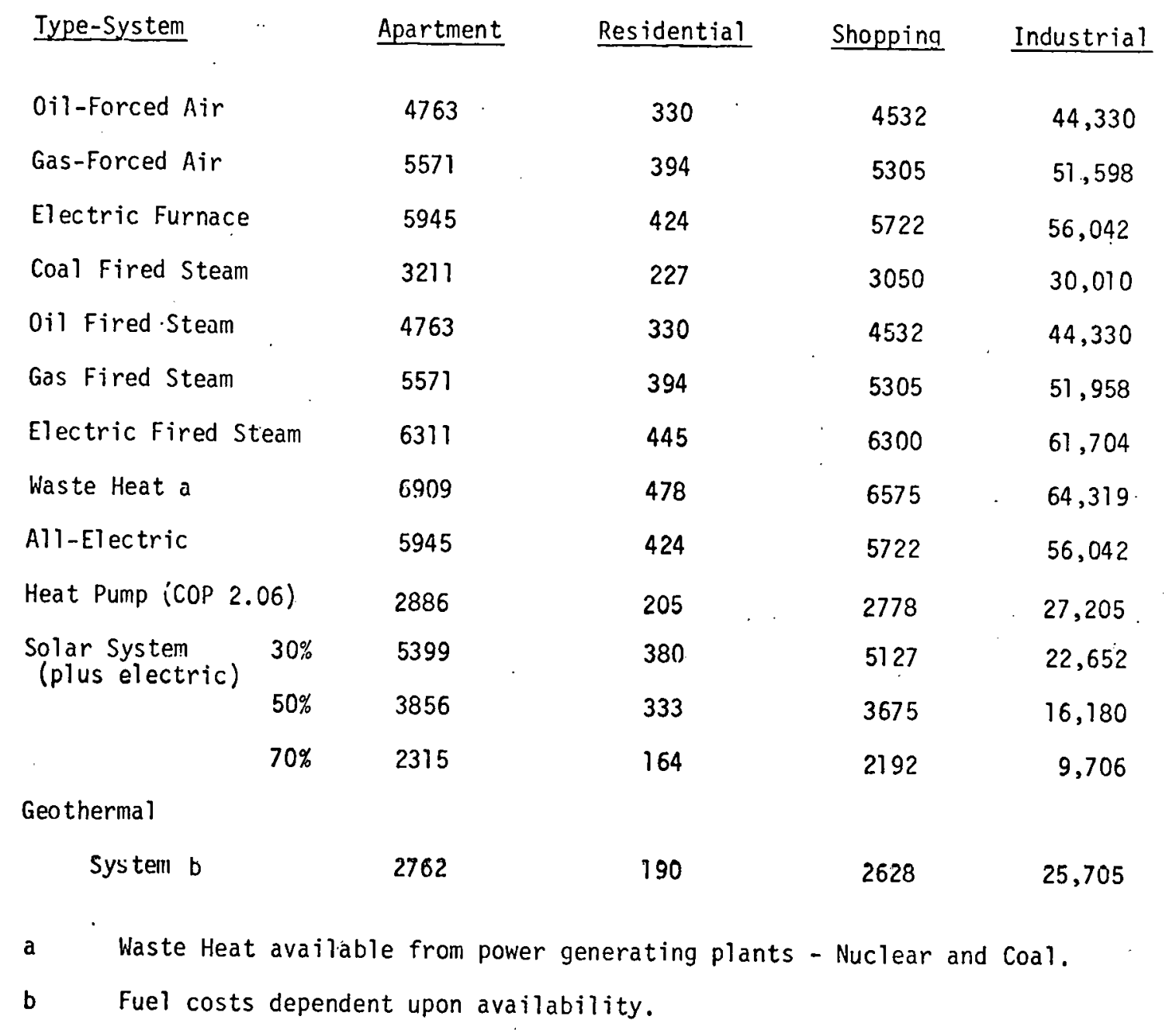


TABLE $X$

Annual Fuel Cost - San Francisco, California (Dollars/Year)

\begin{tabular}{|c|c|c|c|c|}
\hline Iype of System & Apartment & Residential & Shopping & Industrial \\
\hline 0i1-Forced Air & 6544 & 453 & 6226 & 60,842 \\
\hline Gas-Forced Air & 7654 & 541 & 7288 & 71,385 \\
\hline Electric Furnace & 8265 & 583 & 7860 & 34,680 \\
\hline Coal Fired Steam & 4402 & 312 & 4190 & 41,112 \\
\hline 0il Fired Steam & 6544 & 453 & 6226 & 60,842 \\
\hline Gas Fired Steam & 7654 & 541 & 7288 & 71,182 \\
\hline Electric Fired Steam & 8672 & 612 & 8655 & 36,295 \\
\hline Waste Heat & 9493 & 656 & 7437 & 88,115 \\
\hline All-Electric & 8265 & .583 & 7860 & 34,680 \\
\hline Heat Pump (COP 2.5) & 3306 & 233 & 3144 & 13,872 \\
\hline Solar System $\quad 30 \%$ & 9418 & 522 & 7044 & 31,035 \\
\hline $50 \%$ & 52.98 & 375 & $50.5 n$ & 27,165 \\
\hline $70 \%$ & 3179 & 225 & 3013 & 13,297 \\
\hline Geothermal System & 3795 & 262 & 2970 & 35,210 \\
\hline
\end{tabular}


TABLE XI

Annual Fuel Cost - Boise, Idaho (Dollars/Years)

\begin{tabular}{|c|c|c|c|c|c|}
\hline \multicolumn{2}{|l|}{ Type of System } & Apartment & Residential & Shopping & Industrial \\
\hline \multicolumn{2}{|l|}{ 0il-Forced Air } & 8494 & 588 & 8082 & 79058 \\
\hline \multicolumn{2}{|l|}{ Gas-Forced Air } & 9935 & 702 & 9460 & 92,661 \\
\hline \multicolumn{2}{|l|}{ Electric Furnace } & 10,729 & 757 & 10,205 & 45,011 \\
\hline \multicolumn{2}{|l|}{ Coal Fired Steam } & 5715 & 405 & 5440 & 53,520 \\
\hline \multicolumn{2}{|l|}{ 0il Fired Steam } & 8494 & 588 & 8082 & 79,058 \\
\hline \multicolumn{2}{|l|}{ Gas Fired Steam } & 9935 & 702 & 9460 & 92,661 \\
\hline \multicolumn{2}{|c|}{ Electric Fired Steam } & 11,255 & 795 & 11,234 & 47,248 \\
\hline \multicolumn{2}{|l|}{ Waste Heat } & 12,324 & 852 & 11,727 & 114,706 \\
\hline \multicolumn{2}{|l|}{ All-Electric } & 10,729 & 757 & 10,205 & 45,011 \\
\hline \multicolumn{2}{|c|}{ Heat Pump (COP 2.06) } & 5,208 & 367 & 4,953 & 21,850 \\
\hline \multirow{3}{*}{$\begin{array}{l}\text { Solar System } \\
\text { (plus electric) }\end{array}$} & $30 \%$ & 9630 & 678 & 9144 & 40,398 \\
\hline & $50 \%$ & 6877 & 487 & 6555 & 28,854 \\
\hline & $70 \%$ & 4127 & 291 & 3910 & 17,310 \\
\hline \multicolumn{2}{|l|}{ Geothermal System } & 4934 & 340 & 4682 & 45,925 \\
\hline
\end{tabular}


TABLE XII

Annual Fuel Cost - Idaho Falls, Idaho (Dollars/Year)

\begin{tabular}{|c|c|c|c|c|c|}
\hline \multicolumn{2}{|l|}{ Type of System } & Apartment & Residential & Shopping & Industrial \\
\hline \multicolumn{2}{|l|}{ 0i1-Forced Air } & 12,702 & 882 & 12,123 & 118,587 \\
\hline \multicolumn{2}{|l|}{ Gas-Forced Air } & 14,902 & 1053 & 14,190 & 138,991 \\
\hline \multicolumn{2}{|l|}{ Electric Furnace } & 16.093 & 1135 & 15,307 & 67,516 \\
\hline \multicolumn{2}{|l|}{ Coal Fired Steam } & 8,572 & 607 & 8,160 & 80,280 \\
\hline \multicolumn{2}{|l|}{ 0il Fired Steam } & 12,741 & 882 & 12,123 & 118,587 \\
\hline \multicolumn{2}{|l|}{ Gas Fired Steam } & 14,902 & 1053 & 14,190 & 144,991 \\
\hline \multicolumn{2}{|c|}{ Electric Fired Steam } & 16,882 & 1192 & 16,851 & 70,872 \\
\hline \multicolumn{2}{|l|}{ Waste Heat } & 18,486 & 1278 & 17,590 & 172,059 \\
\hline \multicolumn{2}{|l|}{ All-Electric } & 16,093 & 1135 & 15,307 & 67,516 \\
\hline \multicolumn{2}{|c|}{ Heat Pump (COP 2.8)* } & 8,940 & 630 & $5,467^{\star \star}$ & $24,113^{\star \star}$ \\
\hline \multirow{3}{*}{$\begin{array}{l}\text { Solar System } \\
\text { (plus electric) }\end{array}$} & $30 \%$ & 14,445 & 1017 & 13,716 & 60,591 \\
\hline & $50 \%$ & 10,315 & 730 & 9,832 & 43,281 \\
\hline & $70 \%$ & 6,190 & 436 & 5,865 & 25,965 \\
\hline \multicolumn{2}{|l|}{ Geothermal System } & 7,401 & 510 & 7,023 & 68,887 \\
\hline
\end{tabular}

* For Idaho Falls, the water "cooled" heat pump is the preferred choice, giving a COP of approximately 2.8, and decreasing the quoted fuel costs by $36 \%$. However, commercial units for residential and apartment use are not generally available as' of this date.

** Water "cooled" units. 


\section{$5.0 \quad$ CAPITAL COSTS}

The cost of heating systems and their installation charges are estimated per building type per location and are listed in Tables XIII, XIV, XV, and XVI for Pendelton, San Francisco, Boise, and Idaho Falls, respectively. Estimates were based on averages of vendor catalogs, brochures and conversations with local Idaho heating companies. Steam systems were all estimated on a two-pipe distribution network and with all components of construction approximately similar, thus reflecting variations of systems per energy source used. $0 i 1$ fired systems naturally reflect a higher initial investment because of greater controlling practices for oil utilization.

Large buildings (Industrial and Shopping Centers) require first cost whose material costs were estimated at $25 \%$ total construction cost. 
TABLE XIII

First Costs - Pendelton, Oregon (Dollars)

\begin{tabular}{|c|c|c|c|c|c|}
\hline \multicolumn{2}{|l|}{ Type of Sys tem } & Apartment & Residential & Shopping & Industrial \\
\hline 0il-Forced Air F & rnace & 28,616 & 1915 & 69,800 & 462,815 \\
\hline Gas-Forced Air F & rnace & 27,397 & 1836 & 67,262 & 445,820 \\
\hline Eléctric-Forced & ir Fur. & 26,227 & 1760 & 64,579 & 427,640 \\
\hline Coal Fired Steam & & 56,110 & 3606 & 104,266 & 740,313 \\
\hline 0il Fired Steam & & 37,210 & 2470 & 89,586 & 597,080 \\
\hline Gas Fired Steam & & 35,830 & 2381 & 86,348 & 575,141 \\
\hline Electric Fired S & eam & 34,326 & 2284 & 82,925 & 551,948 \\
\hline Waste Heat & & 25,200 & 1027 & 59,033 & 400,000 \\
\hline Geothermal & & 25,200 & 1027 & 59,033 & 400,000 \\
\hline Total Electric & & 33,673 & 2100 & 73,792 & 483,750 \\
\hline Heat Pump & - & 48,229 & 317 & 106,465 & 888,027 \\
\hline \multirow{3}{*}{$\begin{array}{l}\text { Solar System } \\
\text { (A) }\end{array}$} & $30 \%$ & 80,214 & 4.943 & 153,638 & $1,041,880$ \\
\hline & $50 \%$ & 87,775 & 5488 & 160,847 & $1,113,9 / 0$ \\
\hline & $70 \%$ & 95,335 & 6032 & $168,0.55$ & $1,186,058$ \\
\hline
\end{tabular}

(A) Solar Systems are estimated at supplying 30, 50 or $70 \%$ of the annual heating load in Northwestern cities. Suppleiental heat is supplied by an electric system by $70 ; 50$, and $30 \%$. (\$8-10/sq ft for $350 \mathrm{Btu} / \mathrm{hr}$ solar collector plus storage tank and piping.) 
TABLE XIV

First Costs - San Francisco, California (Dollars)

\begin{tabular}{|c|c|c|c|c|c|}
\hline Type of System & & Apartment & Residential & Shopping & Industrial \\
\hline 0 il-Forced Air & Furnace & 27,616 & 1816 & 69,120 & 449,454 \\
\hline Gas-Forced Air & Furnace & 26,498 & 1742 & 66,410 & 432,259 \\
\hline Electric-Forced & Air Fur. & 25,438 & 1672 & 63,835 & 414,081 \\
\hline Coal Fired Stean & & 46,845 & 3340 & 97,147 & 678,827 \\
\hline 0 il Fired Steam & & 35,406 & 2329 & 88,190 & 574,550 \\
\hline Gas Fired Steam & & 34,026 & 2240 & 84,952 & 561,580 \\
\hline Electric Fired & Steam & 32,522 & 2143 & 81,529 & 538,387 \\
\hline Waste Heat & & 21,420 & 872 & 50,178 & 387,000 \\
\hline Geotherma ] & & 21,420 & 872 & 50,178 & 387,000 \\
\hline All Electric & & 28,622 & 1785 & 62,723 & 483,750 \\
\hline Heat Pump (1) & & 37,350 & 2450 & 89,895 & 687,715 \\
\hline Solar System & $30 \%$ & 66,350 & 4200 & 130,592 & 885,600 \\
\hline & $50 \%$ & $71,8.98$ & 4665 & 136,720 & 946,875 \\
\hline & $70 \%$ & 77,426 & 5128 & 142,846 & $1,008,150$ \\
\hline
\end{tabular}

(1) Every 10 years a new compressor $0 \$ 400$ is needed for a $63 \mathrm{MBH}$ heat pump. Thus its life expectency is' 25 years with installation of a new compressor each 10 years. 
TABLE XV

First Costs - Boise, Idaho (Dollars)

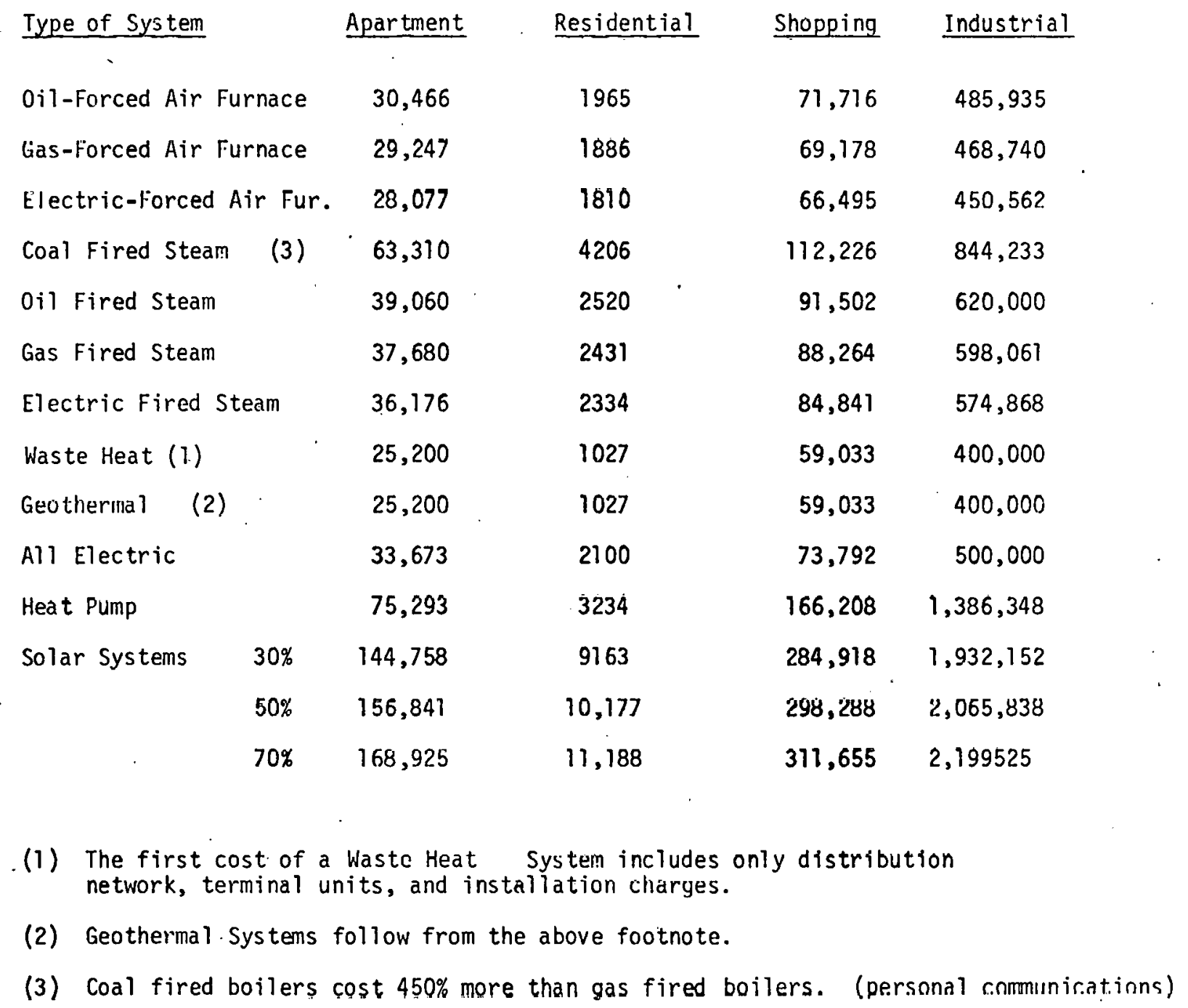


TABLE XVI

First Costs - Idaho Falls, Idaho (Dollars)

\begin{tabular}{|c|c|c|c|c|}
\hline Type of System & Apartment & Residential & Shopping & Industrial \\
\hline 0il-Forced Air Furnace & 31,685 & 2043 & 74,585 & 505,372 \\
\hline Gas-Forced Air Furnace & 30,416 & 1961 & 71,945 & 487,489 \\
\hline Electric-Forced Air Fur. & 29,200 & 1882 & 69,155 & 468,584 \\
\hline Coal Fired Steam & 65,842 & 4374 & 116,715 & 878,002 \\
\hline 0 il Fired Steam & 40,622 & 2620 & 95,162 & 644,800 \\
\hline Gas Fired Steam & 39,187 & 2528 & 91,795 & 621,983 \\
\hline Electric Fired Steam & 37,623 & 2427 & 88,234 & 597,862 \\
\hline Waste Heat & 26,208 & 1068 & 61,395 & 416,000 \\
\hline Geothermal & 26,208 & 1068 & 61,395 & 416,000 \\
\hline Total Electric & 35,019 & 2184 & 76,744 & 520,000 \\
\hline Heat Pump & 78,304 & 3363 & 172,856 & $1,441,801$ \\
\hline \multirow[t]{3}{*}{ Solar System } & 151,660 & 9599 & 298,504 & $2,024,300$ \\
\hline & 164,320 & 10,662 & 312,512 & $2,164,350$ \\
\hline & 176,980 & 11,721 & 326,516 & $2,304,410$ \\
\hline
\end{tabular}




\subsection{TOTAL COSTS OF HEATING SYSTEMS}

The preceding tables list annual fuel cost and first costs. Each of the system's life expectency is 1 isted in Table VIII. Using straightline depreciation of the first cost assuming cost of capital for the installation is 10\% over its expected 1ife period and adding annual fuel cost and maintenance to the annual capital cost thus figured, the total annual heating cost is thereby calculated. It is assumed that the system experiences no loss of efficiency with continued use and therefore annual fuel cost remains constant. Tables XVII, XVIII, XIX, and XX for Pendelton, San Francisco, Boise, and Idaho Falls, respectively, list the annual heating costs of the various systems described in this report.

Maintenance costs have not been included for the shopping centers, apartments, and industrial installation columns, since these units will require a full time maintenance staff. Hence, it is believed that total maintenance charges will not differ much for each of the systems considered.

However, for residential units, the bulk of the maintenance is anticipated to be for equipment repair. The annual costs for maintenance are as estimated below:

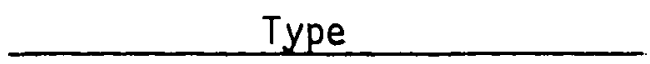

0il, gas, coal furnaces

Electric furnaces

Total Electric (baseboard)

Geotherma]

Solar

Heat Pump

0il, Gas \& Coal Steam Systems
Estimated Annual Residential Maintenance

$\$ 40$ 
ANNUAL hEATING COSTS - PENDELTON, OREGON (DOLLARS)

\begin{tabular}{|c|c|c|c|c|c|}
\hline Type of System & \multicolumn{2}{|c|}{ Apartment } & Residential & Shopping & Industrial \\
\hline 0il-Forced Air & Furnace & 13,974 & 976 & 27,000 & 193,307 \\
\hline Gas-Forced Air & Furnace & 14,390 & 1015 & 26,956 & 195,105 \\
\hline Electric-Forcec & Air & 12,909 & 911 & 22,870 & 169,596 \\
\hline Coal Fired Stea & & 21,272 & 1427 & 36,612 & 268,312 \\
\hline 0il Fired Stean & & 16,740 & 1165 & 33,369 & 236,526 \\
\hline Gas Fired Stean & & 17,105 & 1200 & 33,099 & 237,092 \\
\hline Electric Fired & Steam & 17,360 & 1220 & 32,993 & 239,373 \\
\hline Waste Heat & & 17,830 & 963 & 32,159 & 237,679 \\
\hline Geothermal & & 13,683 & 675 & 28,212 & 199,065 \\
\hline Total Electric & & 14,886 & 991 & 25,316 & 184,496 \\
\hline Heat Pump & & 23,788 & 1639 & 48,919 & 412,075 \\
\hline Solar Systems & $30 \%$ & 31,219 & 2051 & 54,582 & 358,027 \\
\hline & $50 \%$ & $32 ; 110$ & 2179 & 55,450 & 374,761 \\
\hline & $70 \%$ & 33,002 & 2185 & 56,288 & 391,491 \\
\hline
\end{tabular}

(A) Life expectency of Solar Systems we estimated to be 19 years (an average of piping and supplemental electric system life expectency). 
TABLE XVIII

ANNUAL HEATING COST - SAN FRANCISCO, CALIFORNIA (DOLLARS)

\begin{tabular}{|c|c|c|c|c|c|}
\hline Type of System & \multicolumn{2}{|c|}{ Apartment } & Residential & Shopping & Industrial \\
\hline 0il-Forced Air & Eurnace & 15,433 & 1067 & 28,475 & 205,518 \\
\hline Gas-Forced Air & Eurnace & 16,183 & 1131 & 28,665 & 210,526 \\
\hline Electric-Forced & Air & 15,019 & 1056 & 24,810 & 144,634 \\
\hline Coal Fired Stea & & 19,481 & 1417 & 35,461 & 259,623 \\
\hline $0 i 1$ Fired Steam & & 17,941 & 1242 & 34,613 & $245,7.86$ \\
\hline Gas Fired Steam & & 18,607 & 1302 & 34,633 & 251,952 \\
\hline Electric Fired & Steam & 19,140 & 1342 & 34,899 & 209,599 \\
\hline Waste Heat & & 18,776 & 1073 & 29,184 & 255,840 \\
\hline Geothermal & & 13,078 & 680 & 24,717 & 202,935 \\
\hline Total Electric & & 15,865 & 1067 & 24,515 & 163,134 \\
\hline Heat Pump & & 19,494 & 1355 & 42,105 & 311,927 \\
\hline Solar System & $30 \%$ & 30,775 & 1954 & 49,080 & 316,105 \\
\hline & $50 \%$ & 28,438 & 1956 & 49,059 & 326,959 \\
\hline & $70 \%$ & 28,102 & 1957 & 48,994 & 337,815 \\
\hline
\end{tabular}


TABLE XIX

ANNUAL HEATING COST - BOISE, IDAHO (DOLLARS)

\begin{tabular}{|c|c|c|c|c|c|}
\hline Type of System & & partment & Residential & Shopping & Industrial \\
\hline 0il-Forced Air & Furnace & $18,30 u$ & 1250 & 37,167 & 235,478 \\
\hline Gas-Forced Air & Furnace & 19,349 & 1339 & 31,728 & 243,546 \\
\hline Electric-Forced & Air & 18,184 & 1257 & 27,862 & 164,652 \\
\hline Coal Fired Stea & & 26,094 & 1798 & 41,565 & 325,274 \\
\hline 0i1 Fired Stean & & 21,067 & 1439 & 37,536 & 278,633 \\
\hline Gas Fired Stean & & 22,064 & 1524 & 37,871 & 285,174 \\
\hline Electric Fired & Steam & 22,899 & 1566 & 38,544 & 232,295 \\
\hline Waste Heat & & 23,245 & 1337 & 37,312 & 288,066 \\
\hline Geothermal & & 15,855 & 825 & 30,266 & 219,285 \\
\hline Total Electric & & 19,670 & 1325 & 29,799 & 177,780 \\
\hline Heat Pump & & 37,839 & 1828 & 76,987 & 622,693 \\
\hline Solar System & $30 \%$ & 56,226 & 3707 & 100,857 & 662,347 \\
\hline & $50 \%$ & 57,363 & 3843 & 102,572 & 693,836 \\
\hline & $70 \%$ & 58,503 & 3972 & 104,230 & 725,325 \\
\hline
\end{tabular}


TABLE XX

ANNUAL HEATING COST - IDAHO FALLS, IDAHO (DOLLARS)

Type of System Apartment Residential Shopping Industrial

\begin{tabular}{|c|c|c|c|c|c|}
\hline \multicolumn{2}{|c|}{ 0il-Forced Air Furnace } & 22,901 & 1569 & 36,131 & 281,264 \\
\hline \multicolumn{2}{|c|}{ Gas-Forced Air, Furnace } & 24,693 & 1714 & 37,348 & 295,911 \\
\hline \multicolumn{2}{|c|}{ Electric-Forced Air } & 23,846 & 1655 & 33,670 & 191,943 \\
\hline \multicolumn{2}{|c|}{ Coal Fired Steam } & 29,766 & 2055 & 45,730 & 362,904 \\
\hline \multicolumn{2}{|l|}{$0 i 1$ Fired Steam } & 25,817 & 1765 & 42,755 & 326,145 \\
\hline \multicolumn{2}{|l|}{ Gas Fired Steam } & 27,516 & 1907 & 43,738 & 345,204 \\
\hline \multicolumn{2}{|c|}{ Electric Fired Steam } & 28,992 & 1993 & 45,253 & 263,320 \\
\hline \multicolumn{2}{|l|}{ Waste Heat } & 29,844 & 1780 & 44,198 & 352,353 \\
\hline \multicolumn{2}{|l|}{ Geothermal } & 18,759 & 1013 & 33,631 & 249,181 \\
\hline \multicolumn{2}{|l|}{ Total Electric } & 25,391 & 1725 & 35,685 & 205,596 \\
\hline \multicolumn{2}{|l|}{ Heat Pump } & 42,877 & 2147 & 80,383 & 648,990 \\
\hline \multirow{3}{*}{ Solar System } & $30 \%$ & 63,263 & 4187 & 807, 109 & $71 \angle, 208$ \\
\hline & $50 \%$ & 63,208 & 4242 & 110,428 & 739,974 \\
\hline & $70 \%$ & 63,159 & 4289 & 110,968 & 767,742 \\
\hline
\end{tabular}




\subsection{CONCLUSIONS}

Approximately $18 \%$, or $14 \times 10^{15} \mathrm{Btu} /$ year of the total U.S. energy demand (1975) is utilized in the space heating of U.S. buildings. This space heating requirement will continue to increase, thus necessitating the use of conservation methods applied to heating systems using depleting resources or the introduction of alternative resources, heretofore, unused. Conservation, by its nature, can effect substantial benefits, but only on a short term basis. The initiation of alternate resources not only transfers up to $18 \%$ of U.S. energy demands on existing sources over for uses of non-heat energy but allows conservation of fossil fuels to have an extended term.

Prior to the current energy crisis, the capital costs of heating systems provided a major deciding factor as to the type of system installed in new building constructions or replacement of older heating systems. As has been presented, other factors may have large influences and should be weighted accordingly in selections of space heating systems. These factors include: capital costs, expected life of the heating system, fuel cost, projected fuel cost and resource availability, efficiency and locality.

These factors must be discussed independently to arrive at weighting to be attached to each. Only after all weighting factors have been averaged in is it possible to provide a basis for selection.

The last of these factors, locality, is useful in determining the weight factor attached to fuel costs. Larger heat losses associated with colder climates increase the relative importance of proper resource selection and tend to decrease the importance of capital cost. To this end, the cost analysis was based on four localities, each of varying climatic conditions. For example, analysis of apartment utilizing oil furnaces:

\begin{tabular}{|c|c|c|c|}
\hline . & $\begin{array}{c}\text { Annual Fuel } \\
\text { Costs } \\
\end{array}$ & $\begin{array}{c}\text { Capital } \\
\text { Costs } \\
\end{array}$ & $\begin{array}{l}\text { Total Annual } \\
\text { Costs } \\
\end{array}$ \\
\hline Idaho Falls, Idaho & $\$ 12,702$ & $\$ 31,685$ & $\$ 22,901$ \\
\hline San Francisco, Cal ifornia & 6,544 & 27,616 & 15,433 \\
\hline Variance & $19.4 \%$ & $115 \%$ & $148 \%$ \\
\hline
\end{tabular}

Capital costs are only 115\% greater for Idaho Falls, Idaho for apartments operating oil furnaces. This ratio is generally true for each system used representative of the fact that heating system size is based on expected temperature extremes. The duration of the heating season and the hours/day a heating system is utilized effects primarily the fuel consumption ration. Thus, Idaho Falls, Idaho experiences 194\% greater annual fuel cost that San Francisco (apartments using oil furnaces). The total annual heating costs, up $148 \%$ in Idaho Falls, Idaho, reflects primarily the fuel cost weighting factor.

The fuel cost weighting factor is directly proportionate to anticipated resource avallability. Future depletion of fossil fuels and therefore increased costs will substantially increase the importance of heating system selection based on fuel costs rather than capital costs. 
The life expectency, likewise a primary factor in calculations of the total annual heating cost, is independent, for the most part, of locality. For example:

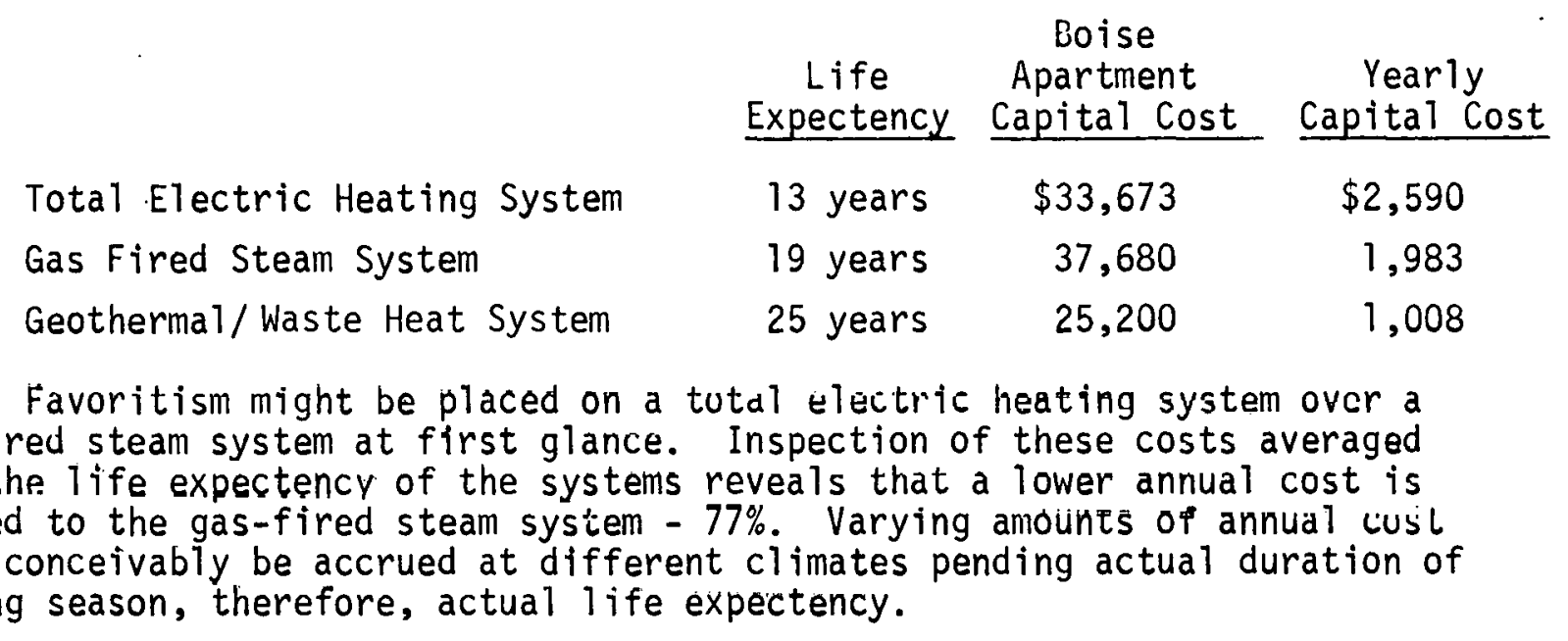

Efficiency of a heating system governs the quantity of heat retrievable from the intrinsic heat of the resource. Inefficiencies arise from energy conversion of fuels used indirectly and/or from the heating systems capability to transmit the available direct heating. The efficiencies listed in Table VIII represent the heating system's ability to transmit the available heat. The heat content of the various resources are indicative of any conversion losses from one energy source to another and are also listed in Table VIII.

These efficiency percentages govern to a large extent the quantity of fuel/ resource consumed. Suggested efficiency rates are normally certified under steady state conditions and do not necessarily remain constant with extended use. Heat losses arising from inefficiency, are for the most part, irretrievable, in air handling fieating systems. Hot water/steam systems are closer to operating efficientiy, owing to recirculation within a closed system or allermative uses in the case of waste heat from generating plants.

of the above factors considered for analysis, each tends to be individually weighted such that percentage importance is exhibited in the total annual heating costs. Colder climates would represent the maximum utilization of each heating resource and would give the appropriate weighting of selection factors (exclusive of capital costs). Table XX, for example, lists the annual heating costs in Idaho Falls, Idaho. Analysis of least cost systems is fair only to the extent that it is exclusive of future availability and cost. For apartment utilization, the 10 least cost systems in order of costs are:

1. Geothermal Heating System (where resource is available)

2. $0 i 1$ Fired Furnace

3. Electric Forced Air Furnace

4. Gas Forced Air Furnace

5. Total Electric 
6. $0 i 1$ Fired Steam

7. Gas Fired Steam

8. Electric Fired Steâm

9. Coal Fired Steam

10. Waste Heat

The above reflect 1975 costs of space heating systems. 


\section{REFERENCES}

(1) U.S. Energy Outlook, National Petroleum Council, Second Printing, December 1972.

(2) A System Analysis of the Economic Utilization of Warm Water Discharge From Power Generating Stations, Oregon State University, 1974.

(3) Handbook of Air Conditioning, Heating and Ventilating, The Industrial Press, 1959.

(4) American Society of Heating, Refrigerating and Air Conditioning Engineers (ASHRAE) Fundamentals, Clifford Strock, Industrial Press, 1959.

(5) ASHRAE - Syat.ems, 1973.

(6) ASHRAE - Guide and Data Book, 1972.

(7) American Boiler Association.

(8) SNF/NASA Solar Energy Panel. Solar Energy as a National Resource, University of Maryland, College Park, 1972.

(9) H. C. Hottel, Solar Energy, Chemical Engıneering Progress, Vol. 71, No. 7, July 1975.

(10) ASHRAE - Applications 59.14, 1974.

(11) H. L. and H. J. L. Thomason, Solar House Plans, Edmund Scientific Company, Barrington, N. J. 1972.

(12) K. Boer, $\Lambda$. Combined Solar Thermal Electriçal Hnise, Paper No. EH-108, I.S.E.S. Congress, Paris, 1973.

(13) Federal Power Commission, The 1970 National Power Survey Part I. 1971, U.S. Government Printing Office, Washington, U.C., December 197 ? 
DISTRIBUTION RECORD FOR ANCR-1276

\section{Externa]}

601 - UC-95d, Energy Conservation--Business and Industry, TID-4500, R63

\section{Internal}

1 - Chicago Patent Group - ERDA 9800 South Cass Avenue Argonne, Illinois 60439

3 - A. T. Morphew, Classification and Technical Information Officer ERDA-ID

Idaho Falls, Idaho 83401

31 - INEL Technical Library

$40=$ Authors 